medRxiv preprint doi: https://doi.org/10.1101/2021.09.08.21263248; this version posted September 12, 2021. The copyright holder for this preprint (which was not certified by peer review) is the author/funder, who has granted medRxiv a license to display the preprint in perpetuity. It is made available under a CC-BY-NC-ND 4.0 International license .

\title{
1 Low dose prime and delayed boost can improve COVID-19 vaccine efficacies by 2 increasing B cell selection stringency in germinal centres
}

4 Amar K. Garg ${ }^{1, \#, ~ S o u m y a ~ M i t t a l ~}{ }^{1}$, Pranesh Padmanabhan ${ }^{2}$, Rajat Desikan ${ }^{1, \ddagger}$, Narendra M. Dixit $^{1,3, *}$

5

$6 \quad{ }^{1}$ Department of Chemical Engineering, Indian Institute of Science, Bangalore, India 560012

$7 \quad{ }^{2}$ Clem Jones Centre for Ageing Dementia Research, Queensland Brain Institute, The University of Queensland,

8 Brisbane, Australia 4072

$9 \quad{ }^{3}$ Centre for Biosystems Science and Engineering, Indian Institute of Science, Bangalore, India 560012

10 \#Current Address: Helmholtz Centre for Infection Research, Braunschweig, Germany

$11{ }^{\ddagger}$ Current Address: Certara QSP, Certara UK Limited, Sheffield, UK

13 * Correspondence:

14 Narendra M. Dixit

15 Email: narendra@iisc.ac.in

16 Address: Department of Chemical Engineering, Indian Institute of Science, Bangalore, 560012, Karnataka, 17 India 
medRxiv preprint doi: https://doi.org/10.1101/2021.09.08.21263248; this version posted September 12, 2021. The copyright holder for this preprint (which was not certified by peer review) is the author/funder, who has granted medRxiv a license to display the preprint in perpetuity. It is made available under a CC-BY-NC-ND 4.0 International license .

\section{ABSTRACT}

24 The efficacy of COVID-19 vaccines appears to depend in complex ways on the vaccine dosage 25 and the interval between the prime and boost doses. Unexpectedly, lower dose prime and longer 26 prime-boost intervals have yielded higher efficacies in clinical trials. To elucidate the origins 27 of these effects, we developed a stochastic simulation model of the germinal centre (GC) 28 reaction and predicted the antibody responses elicited by different vaccination protocols. The 29 simulations predicted that a lower dose prime could increase the selection stringency in GCs 30 due to reduced antigen availability, resulting in the selection of GC B cells with higher affinities 31 for the target antigen. The boost could relax this selection stringency and allow the expansion 32 of the higher affinity GC B cells selected, improving the overall response. With a longer dosing 33 interval, the decay in the antigen with time following the prime could further increase the 34 selection stringency, amplifying this effect. The effect remained in our simulations even when 35 new GCs following the boost had to be seeded by memory B cells formed following the prime. 36 These predictions offer a plausible explanation of the observed paradoxical effects of dosage 37 and dosing interval on vaccine efficacy. Tuning the selection stringency in the GCs using 38 prime-boost dosages and dosing intervals as handles may help improve vaccine efficacies. 
medRxiv preprint doi: https://doi.org/10.1101/2021.09.08.21263248; this version posted September 12, 2021. The copyright holder for this

preprint (which was not certified by peer review) is the author/funder, who has granted medRxiv a license to display the preprint in perpetuity.

It is made available under a CC-BY-NC-ND 4.0 International license .

39

40

41

42

43

44

45

46

47

48

49

50

51

52

53

54

55

56

57

58

59

60

\section{INTRODUCTION}

The COVID-19 pandemic continues to rage and warrants intensifying the ongoing global

vaccination programs $(1,2)$. With limited vaccine supplies, it becomes critical to identify dosing protocols that would maximize vaccine efficacy $(3,4)$. With the Oxford-AstraZeneca vaccine, where dosing protocols were adjusted during the trials, data has become available of the effects of different dosages used for the prime and boost doses and of different intervals separating them on vaccine efficacy (5-8). A recent study has also examined the effects of increasing the interval beyond those in the trials (9). Intriguingly, the efficacy in preventing symptomatic infection was $63.1 \%$ when a standard dose (containing $5 \times 10^{10}$ virus particles) was used for both prime and boost, whereas the efficacy was substantially higher, $80.7 \%$, when a low dose prime (containing $2.2 \times 10^{10}$ virus particles) followed by the standard dose boost was administered (5). Furthermore, the efficacy increased with the interval between the prime and boost, from $55.1 \%$ at $<6$ weeks to $81.3 \%$ at $\geq 12$ weeks, when standard doses were used for both (5). Inspired by these observations, studies are examining the effects of lower dosages and increased dosing intervals with other vaccines too, specifically the Pfizer-BioNTech (10-12) and Moderna (13) vaccines. An understanding of these effects would help identify optimal dosing protocols and maximize the impact of the ongoing vaccination programs. The origins of the effects remain to be elucidated.

While the role of cellular immunity is yet to be fully elucidated (14), several studies suggest that the efficacy of currently approved COVID-19 vaccines is attributable to the 59 neutralizing antibodies they elicit $(6,11,15-20)$. The higher efficacies observed above are thus argued to be due to the improved quality and quantity of the antibodies produced by the 
medRxiv preprint doi: https://doi.org/10.1101/2021.09.08.21263248; this version posted September 12, 2021. The copyright holder for this

preprint (which was not certified by peer review) is the author/funder, who has granted medRxiv a license to display the preprint in perpetuity.

It is made available under a CC-BY-NC-ND 4.0 International license .

61 associated dosing protocols $(5,8,9,11,21)$. For instance, higher antibody levels were observed

62 following the boost upon increasing the dosing interval $(9,10)$. In some cases, antibody63 dependent cellular functions too appeared to be better with the longer intervals (21). A question 64 that arises is how the different dosing protocols elicit antibodies of different amounts and 65 affinities for their targets. Antibody production following vaccination (or natural infection) occurs in germinal can last anywhere from a few weeks to many months (23-25).) This process, termed affinity maturation, culminates, typically in weeks, in the selection of B cells with affinities that can be

72 several orders of magnitude higher for the target antigen than those at the start of the GC 73 reaction $(26,27)$. What determines the final affinities is an important question in immunology 74 and is yet to be resolved (28-30). Several studies have identified factors that influence affinity 75 maturation $(26,31-37)$. A key factor is antigen availability within GCs-related here to the vaccine dosage and antigen half-life-elucidated first by the classic experiments of Eisen and colleagues (26): B cells compete for antigen in the GCs. Their survival depends on how much antigen they acquire, as we explain below. Thus, if antigen is scarce, the selection is stringent phenomenon governing the GC reaction is manifested widely, including in the effects of 81 passive immunization following HIV infection, and can be potentially exploited by tuning 82 antigen availability $(34,35,38,39)$. 
medRxiv preprint doi: https://doi.org/10.1101/2021.09.08.21263248; this version posted September 12, 2021. The copyright holder for this preprint (which was not certified by peer review) is the author/funder, who has granted medRxiv a license to display the preprint in perpetuity.

It is made available under a CC-BY-NC-ND 4.0 International license .

83

84

85

86

87

88

89

90

91

92

93

94

95

96

97

98

99

100

101

102

103

104

Here, we reasoned that one way in which the effects of the different vaccination

protocols could arise was from the influence the protocols had on antigen availability and hence

selection stringency within GCs. Specifically, low dose prime is expected to result in low antigen availability and may lead to the selection of higher affinity B cells. The standard dose boost could then enable the expansion of these higher affinity B cells. With a larger dosing interval, the decay of antigen between doses could cause an increase in selection stringency, resulting in a similar effect. To test this hypothesis, we developed a detailed stochastic simulation model of the GC reaction. Such simulation models have been shown to mimic the GC reaction faithfully and have helped resolve confounding experimental observations and predict optimal vaccination protocols (34-36, 39-44). 3

\section{RESULTS}

\section{Stochastic simulation model of the GC reaction post COVID-19 vaccination}

We present an overview of the model here (Fig. 1); details are in Methods. We considered individuals who were not previously infected and were administered COVID-19 vaccines. We focused on the $\mathrm{GC}$ reaction in such individuals. The simulation, building on previous protocols $(35,36,39,40,42)$, considered and modelled events within an individual GC. The GC reaction is initiated by B cells of low affinity for a target, non-mutating antigen. The target could be a portion of or the entire spike protein of SARS-CoV-2. We simulated the ensuing affinity maturation process using a discrete generation, Wright-Fisher-type, formalism $(36,39)$. The GC is divided into a light zone and a dark zone (Fig. 1A). The antigen is presented in the light zone and is represented as a bit-string of $L$ amino acids. Each B cell is identified by 
medRxiv preprint doi: https://doi.org/10.1101/2021.09.08.21263248; this version posted September 12, 2021. The copyright holder for this

preprint (which was not certified by peer review) is the author/funder, who has granted medRxiv a license to display the preprint in perpetuity.

It is made available under a CC-BY-NC-ND 4.0 International license.

105 its B cell receptor (BCR), which is also represented as a bit-string of $L$ amino acids. The affinity

106

107

108

109

110

111

112

113

114

115

116

117

118

119

120

121

122

123

124

125

126

of a B cell for the antigen is determined by the extent of the match between the BCR and antigen

sequences $(39,42)$, defined here using $\varepsilon . \varepsilon=0$ if the two sequences are completely distinct, whereas $\varepsilon=L$ if they are identical. The higher the $\varepsilon$, the higher is the affinity. In each generation,

we let each B cell have an average of $\eta$ attempts to acquire antigen. $\eta$ thus serves as a surrogate of antigen availability in the GC (39). The probability with which a B cell acquires antigen in each attempt is set proportional to its affinity for the antigen (39). If a B cell fails to acquire a minimum amount of antigen, it is assumed to undergo apoptosis (31), and is eliminated. The surviving B cells then compete for help from $\mathrm{T}$ follicular helper $\left(\mathrm{T}_{\mathrm{fh}}\right)$ cells. The probability that a B cell receives such help is set proportional to the amount of antigen it has acquired relative to that of the other B cells in the generation (39). B cells that do not succeed in receiving $\mathrm{T}_{\mathrm{fh}}$ help are again assumed to undergo apoptosis (31). Among the surviving B cells, following previous studies (39), we let 5\% exit the GC, become plasma cells, and produce antibodies; 5\% exit and become memory B cells; and 90\% migrate to the dark zone, where they proliferate and mutate their BCR genes and return to the light zone $(39,43)$. The latter B cells form the pool for the next generation of the GC reaction. The antibodies produced by plasma cells can feedback into the GC and, by displacing lower affinity antibodies in the immune complexes or by masking antigen, tend to increase the selection stringency $(35,39,45)$.

Following dosing, antigen is trafficked to the lymph nodes, where its levels rise rapidly and then decline exponentially $(34,46)$. Accordingly, we let $\eta$ rise immediately upon dosing to a pre-determined amount dependent on the vaccine dosage and then decrease with each generation based on the half-life of the administered antigen (Fig. 1B). With the boost, we 
medRxiv preprint doi: https://doi.org/10.1101/2021.09.08.21263248; this version posted September 12, 2021. The copyright holder for this preprint (which was not certified by peer review) is the author/funder, who has granted medRxiv a license to display the preprint in perpetuity.

It is made available under a CC-BY-NC-ND 4.0 International license.

127 considered two scenarios $(34,47,48)$ : the first where the boost enhanced antigen levels in pre-

128 existing GCs, and the second where it initiated new GCs using memory B cells formed by the

129 prime.
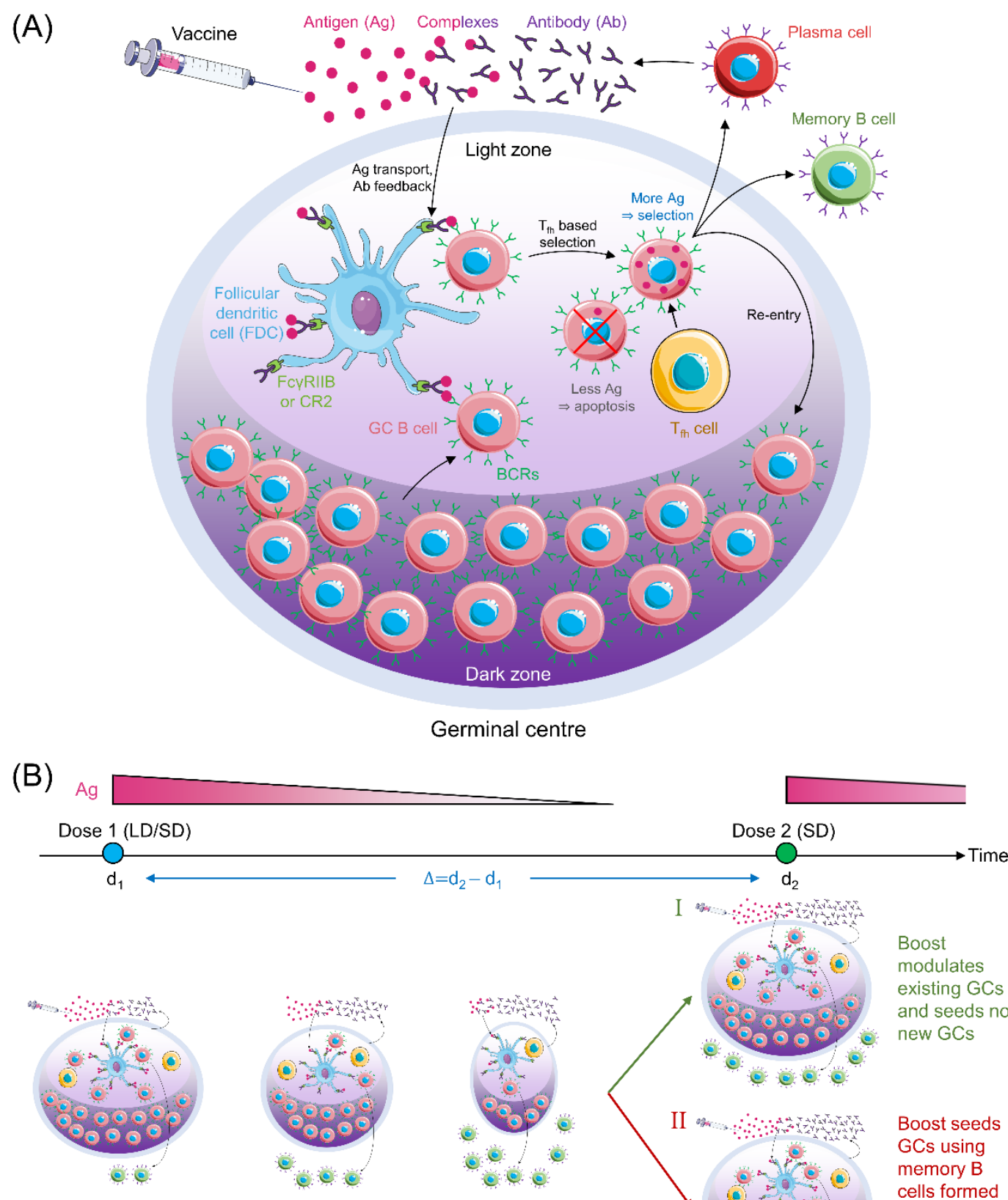

I. Continued existing GC response ('Cont. GC')

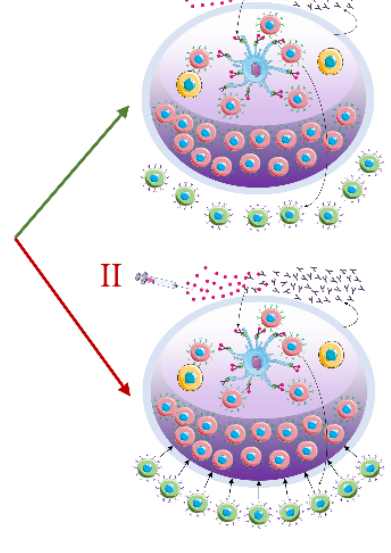

Boost

modulates existing GCs and seeds no new GCs

131 Figure 1. Schematic of the GC reaction model post vaccination. (A) The GC reaction. The 132 antigen from the vaccine enters the GC complexed to antibodies and is presented in the light 133 zone on the surfaces of follicular dendritic cells attached to Fc $\gamma$ RIIB or CR2 receptors. GC B 134 cells acquire antigen with a probability proportional to their affinity for the antigen. They then 
It is made available under a CC-BY-NC-ND 4.0 International license .

135

136

137

138

139

140

141

142

143

144

145

146

147

148

149

150

151

152

153

154

155

156

157

158

159

160

161

receive help from $\mathrm{T}$ follicular helper cells with a probability dependent on the relative amount of antigen they acquired. Cells that fail to acquire antigen or receive the latter help die. Cells that succeed can exit the GC to become plasma cells and secrete antibodies, become memory B cells, or migrate to the dark zone, where they proliferate and mutate their antibody genes. The latter cells circulate back to the light zone and become subjected to the same selection process. Antibodies secreted by plasma cells can feedback into the GC and affect the selection process. (B) Schematic of the simulations. (Top) Timeline showing dose administration and corresponding antigen levels. (Bottom) GCs are formed following the prime and gradually shrink with time due to decreasing antigen levels. The prime could be low dose (LD) or standard dose (SD). The boost could restore existing GCs (mechanism I) or lead to new GCs seeded by memory B cells formed during the prime (mechanism II). The boost is typically SD.

We also examined the baseline, control scenario where the boost initiated GCs de novo, independently of the prime. We considered vaccination protocols with low and standard dose prime and a range of prime-boost dosing intervals. We performed multiple stochastic realizations of the simulations for each vaccination protocol and predicted the expected antibody response as an indicator of vaccine efficacy.

\section{Antigen availability and its effect on selection stringency}

To elucidate affinity maturation in the GC reaction, we first performed simulations with

a constant $\eta$, set here to 7. (We considered other values of $\eta$ later.) The GC initially had B cells

with low affinity for the target antigen. As the GC reaction proceeded, B cells with increasing affinity were selected in our simulations, marking affinity maturation (Fig. 2A). Eventually, a stationary distribution of B cells of different affinities was achieved, dominated by B cells with the highest affinities, as observed in previous studies (39) and akin to the mutation-selection balance observed in other evolutionary simulations $(49,50)$. We focussed on the corresponding evolution of the average affinity of the B cells. As the GC reaction progressed, the average 
medRxiv preprint doi: https://doi.org/10.1101/2021.09.08.21263248; this version posted September 12, 2021. The copyright holder for this preprint (which was not certified by peer review) is the author/funder, who has granted medRxiv a license to display the preprint in perpetuity.

It is made available under a CC-BY-NC-ND 4.0 International license .

162 affinity of the B cells increased and reached a plateau (Fig. 2B). Thus, when $\eta=7$, the average

163 affinity of the B cells, determined by the average match-length between the antigen and BCR

164 sequences, plateaued at $\sim 6.7$ (Fig. $2 \mathrm{~B}$ inset). Note that $L=8$ in these simulations.

(A)

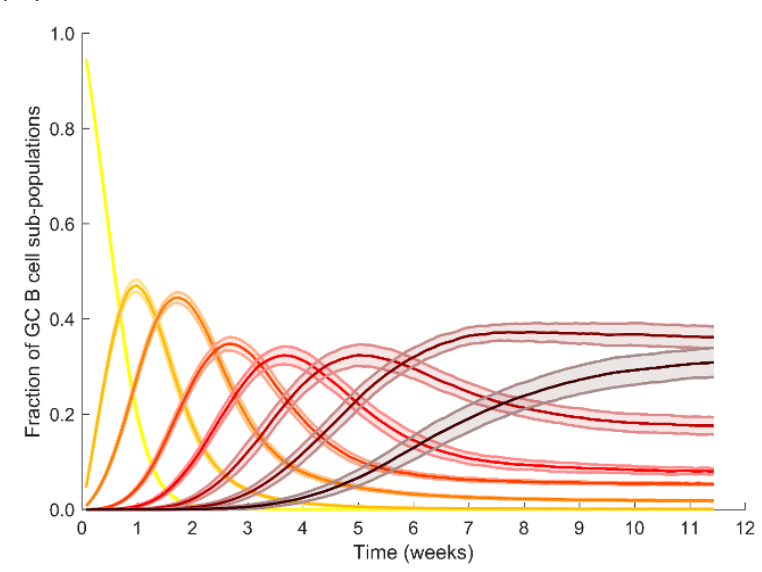

(C)

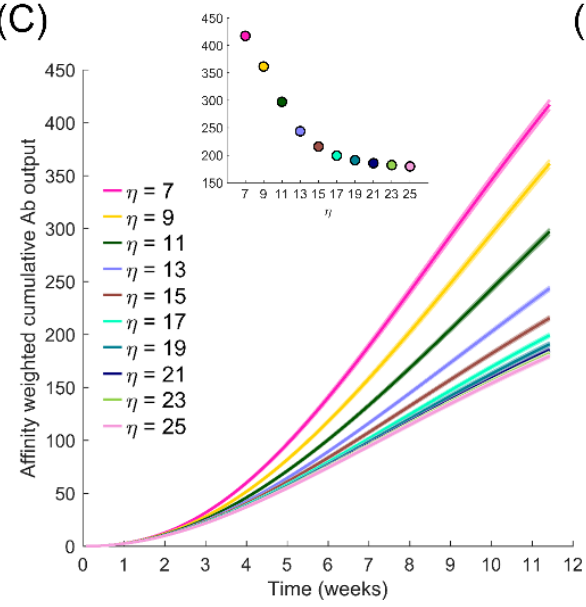

(D)

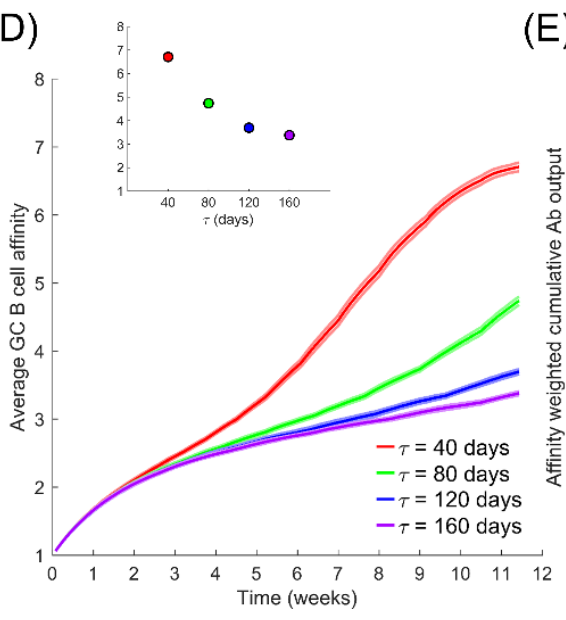

(B)

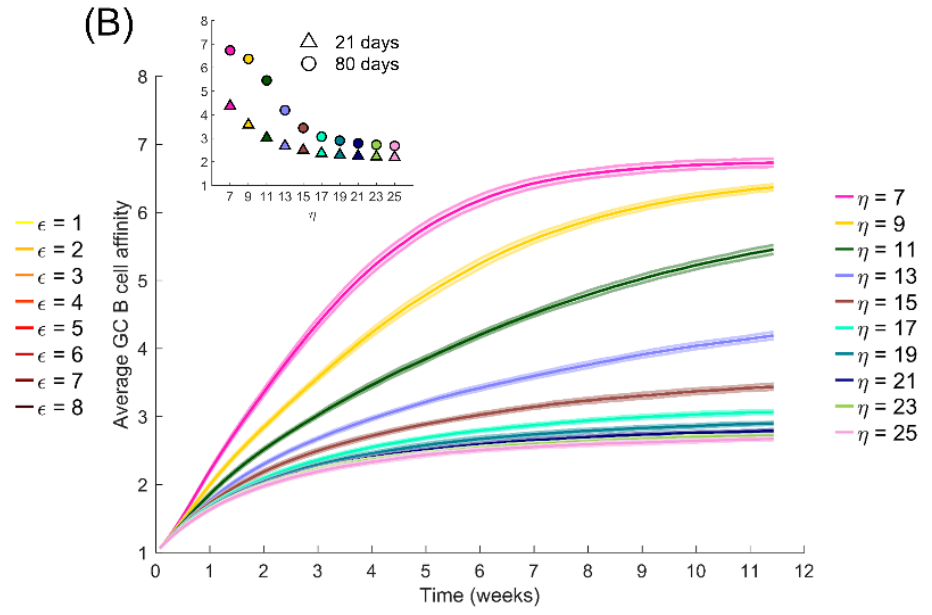

(E)

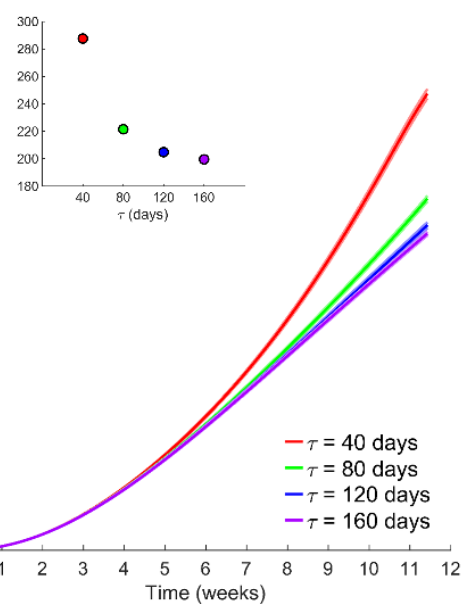

165

166

167

168

169

170

171

172

173

Figure 2. The effect of antigen availability and half-life on the GC reaction. (A) Timeevolution of populations of GC B cells of different affinity, $\varepsilon$, for the antigen; $\eta=7$. (B) Timeevolution of the average affinity of GC B cells for different $\eta$. Inset: The values at day 21 and day 80 , the latter the plateau values, of the average affinity versus $\eta$. (C) Time-evolution of the affinity-weighted cumulative antibody output for different $\eta$. (D) Time-evolution of the

average affinity for different antigen half-lives, $\tau$, and the initial $\eta, \eta_{0}=20$. (E) Corresponding 72 cumulative antibody output. Insets in $(C-E)$ : Corresponding values at day 80. 
medRxiv preprint doi: https://doi.org/10.1101/2021.09.08.21263248; this version posted September 12, 2021. The copyright holder for this preprint (which was not certified by peer review) is the author/funder, who has granted medRxiv a license to display the preprint in perpetuity.

It is made available under a CC-BY-NC-ND 4.0 International license .

175 values of $\eta$. Increasing $\eta$ resulted in a lower value of the plateau of the average affinity (Fig.

176 2B), indicative of weaker selection. Increasing $\eta$ would correspond to higher vaccine dosages.

177 B cells with lower affinities were selected with higher $\eta$ because more opportunities were 178 available for antigen acquisition. Thus, the average affinity plateaued at $\sim 3.4$ when $\eta=15$ and 179 decreased further with larger $\eta$ (Fig. 2B inset). This is consistent with the classic observations 180 of poorer affinity maturation with increasing antigen levels $(26,39)$. In terms of the absolute 181 antibody titres, our simulations predicted that unless the selection stringency was so large that 182 the GC B cell population began to decline causing GC collapse (Fig. S1), the GC B cell 183 population was maintained, leading to a steady output of Abs from the GC (Fig. S2). The lower 184 affinity with increasing $\eta$ thus resulted in a corresponding decrease in the affinity-weighted 185 cumulative antibody output in our simulations (Fig. 2C). The latter output was $\sim 417$ when $\eta=7$ 186 and $\sim 216$ when $\eta=15$ at $80 \mathrm{~d}$ following dosing (Fig. $2 \mathrm{C}$ inset). This affinity-weighted antibody 187 output would serve as a measure of the humoral response elicited by vaccination; it accounts 188 for the effects of both the quality and the quantity of the response. At very high values of $\eta$, 189 beyond $\sim 20$ in our simulations, the effect of varying $\eta$ was minimal (Fig. $2 B$ and C), indicating 190 that at sufficiently high dosages, the effect of varying dosage on the GC reaction may not be 191 significant. At lower $\eta$, between 7 and 15 in our simulations, lowering dosage resulted in a 192 substantial gain in the GC response. When $\eta$ was too low, however, in our simulations, GCs 193 collapsed, as not enough antigen was available for sustaining the B cell population (Fig. S1). 
medRxiv preprint doi: https://doi.org/10.1101/2021.09.08.21263248; this version posted September 12, 2021. The copyright holder for this preprint (which was not certified by peer review) is the author/funder, who has granted medRxiv a license to display the preprint in perpetuity.

It is made available under a CC-BY-NC-ND 4.0 International license .

We therefore next performed simulations with $\eta$ decreasing with a half-life $\tau$; i.e., $\eta=\eta_{0} \exp (-$ antibody output, accordingly, increased with decreasing $\tau$, consistent with an improved response due to increased selection stringency (Fig. 2E).

\section{Prime-boost vaccination: the effect of dosage}

We now applied our simulations to mimic the prime-boost vaccination protocols and standard dose $\left(\eta_{0}=20\right)$ combinations, administered with a dosing interval $\Delta=28 \mathrm{~d}$ mimicking experimental protocols $(5,6,21)$. (Our conclusions are not sensitive to these parameter settings; see Fig. S3) An important aspect of the humoral response associated with 212 multiple antigen dosing that remains unknown is whether the subsequent doses modulate GCs 213 formed following the first dose or seed new GCs. GCs have been observed to persist over 214 extended durations following COVID-19 vaccination (24). (Such persistent GCs have been 
medRxiv preprint doi: https://doi.org/10.1101/2021.09.08.21263248; this version posted September 12,2021 . The copyright holder for this

preprint (which was not certified by peer review) is the author/funder, who has granted medRxiv a license to display the preprint in perpetuity.

It is made available under a CC-BY-NC-ND 4.0 International license .

215 seen following natural infection with other viruses too (25).) If the interval $\Delta$ is relatively small,

216 one may expect the boost to modulate ongoing GC reactions, as has been suggested previously

$217(34,39)$. However, if $\Delta$ is large, then the GCs formed by the prime may collapse due to antigen

218 decay before the boost, so that the seeding of new GCs by the boost is more likely. In the latter

219 scenario, the effect of the prime must come from the preferential seeding by memory B cells

220 formed following the prime $(47,48,53)$. Recruitment of memory B cells into GCs has been

221 suggested, especially those B cells that displayed cross reactivity to other circulating human

222 betacoronaviruses (24). We therefore simulated two limiting scenarios (Fig. 1B): First, we

223 assumed that the boost modulated existing GCs and seeded no new GCs. Second, we let the

224 boost seed GCs using the memory B cells formed from the prime and not modulate any existing

225 GCs. We also simulated a control case where the boost established new GCs de novo, without

226 using memory B cells from the prime, in which case no advantage from the prime is expected.

With the boost modulating existing GCs, our simulations predicted an advantage of the

228 low dose prime over the standard dose prime (blue and red lines in Fig. 3A, B). The average

229 affinity increased with time more steeply with the low dose until day 28 , when the boost was

230 administered (Fig. 3A). Just prior to boost administration, the average affinity was $\sim 4.9$ for the

231 low dose versus $\sim 2.8$ for the standard dose prime. Correspondingly, the affinity-weighted

232 cumulative antibody output was higher for the low dose than the standard dose (Fig. 3B). The

233 administration of the boost caused an increase in antigen availability (Fig. 3A inset), relieving

234 the selection stringency. The average affinity thus saw a temporary dip (Fig. 3A). However, as

235 affinity maturation continued, the higher affinity B cells selected with the low dose prime

236 expanded substantially, yielding a much higher affinity-weighted antibody output than with the 
237 standard dose prime (Fig. 3B). The average affinity and the affinity-weighted cumulative 238 antibody output was higher with the low dose prime than the standard dose prime throughout 239 our simulations.

(A)

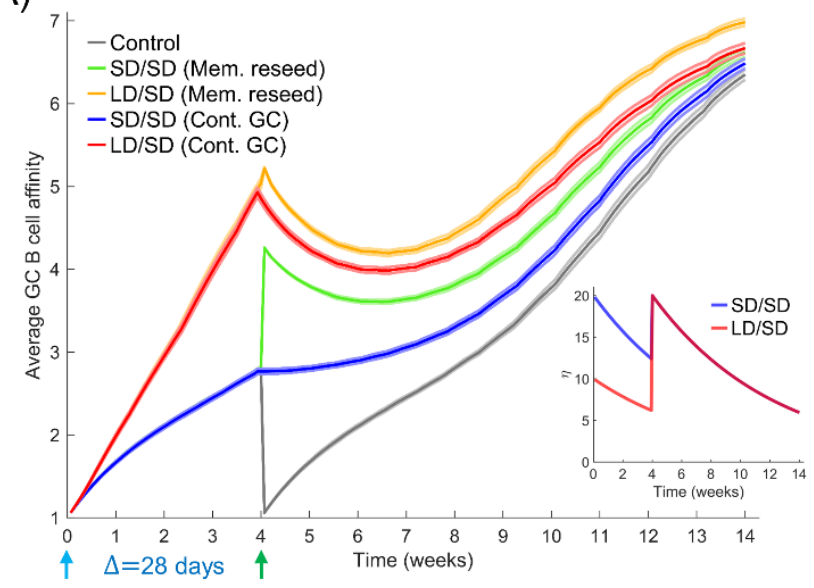

(B)

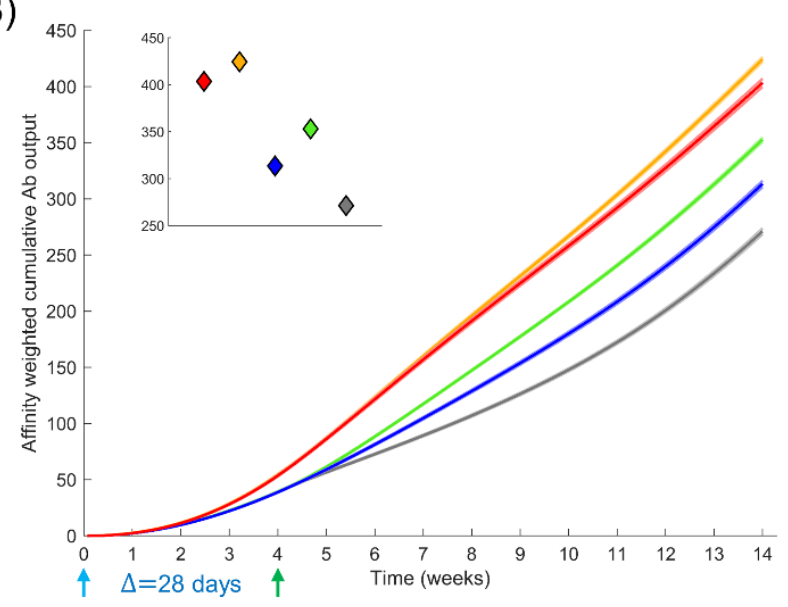

242

243

244

245

246

247

248

249

250

251

252

253

25

255

When we let the boost seed GCs using memory B cells from the prime, the difference

between low dose and standard dose prime was smaller in our simulations following the boost

(green and orange curves in Fig. 3A, B). This is because we assumed that only B cells above a certain affinity for the antigen (here, match length $\geq 3$; see Methods) could differentiate into memory B cells following stimulation. The advantage of the low dose prime in yielding high

254 affinity B cells was thus reduced. The choice of memory B cells is in keeping with the

55 expectation that low affinity naïve-like B cells may not receive strong enough signals to differentiate into switched memory B cells (54). Also, low affinity B cells are likely to exist 
257 regardless and thus seeding GCs with low affinity memory B cells may be no different from 258 seeding GCs de novo. Yet, even within the memory pool, the low dose prime yielded higher 259 affinity B cells than the standard dose prime, explaining the advantage of the low dose prime 260 in our simulations (Fig. 3A). The differences in the corresponding affinity-weighted cumulative 261 antibody output (Fig. 3B) were as expected but commensurately smaller than when the boost 262 seeded existing GCs. Both scenarios yielded better responses than the control case where the boost seeded GCs de novo (grey lines in Fig. 3A, B).

\section{Prime-boost vaccination: the effect of dosing interval}

To assess the influence of the dosing interval, we compared next the antibody responses

275 also significantly higher with the $\Delta=56 \mathrm{~d}$ than $\Delta=28 \mathrm{~d}$ (Fig. 4C, D). For instance, $28 \mathrm{~d}$ after the

276 boost, the output was $\sim 380$ and $\sim 174$, respectively, in the two cases, when low dose prime was

277 used and the boost modulated existing GCs. With standard dose prime too, the difference was 278 nearly 2-fold. This effect remained whether the boost seeded new GCs or modulated surviving 
It is made available under a CC-BY-NC-ND 4.0 International license .

279 GCs (Fig. 4A-D), indicating a distinct advantage of the longer interval. The cases all yielded 280 significantly better responses than the control case where the boost elicited GCs de novo (Fig. 281 4A-D).

283 of varying $\Delta$ for a range of values of $\tau$. Following recent experiments $(9,12)$, we also 284 considered much larger values of $\Delta$; ranging from $28 \mathrm{~d}$ to $84 \mathrm{~d}$ (Figs. $4 \mathrm{E}, \mathrm{F}$ and S4). To evaluate 285 the effect on affinity maturation, we compared the maximum value of the average GC B cell 286 affinity achieved at any time 1 week post the boost (to eliminate transients). We found that at 287 any $\tau$, increasing $\Delta$ increased the peak affinity, regardless of the use of low dose or standard 288 dose prime or whether the boost seeded new GCs or affected existing GCs (Fig. 4E). Thus, a 289 longer duration yielded a GC response of better quality. Further, the lower was $\tau$, the higher 290 was the peak affinity at any $\Delta$, consistent with stronger selection stringency associated with 291 lower antigen availability (Fig. 4E).

292 This latter effect influenced the overall response, combining quality with quantity, which we 293 assessed using the affinity-weighted cumulative antibody output $28 \mathrm{~d}$ post the boost (Fig. 4F). 294 While the overall trend of improved output with longer $\Delta$ remained, the trend was more 295 nuanced. The nuances were due to the complex dynamics of the GC responses following 296 multiple dosing. We examined first the effect of low dose prime. When $\tau$ was large, the GC 297 reaction was sustained longer, allowing greater affinity maturation (Fig. S4). Thus, delayed 298 dosing interval would lead to better responses. Indeed, with $\Delta=56 \mathrm{~d}$ and $\Delta=84 \mathrm{~d}$, our simulations 299 predicted that the cumulative output improved with $\tau$ (Fig. 4F). With $\Delta=28$ d, the GCs may not 
medRxiv preprint doi: https://doi.org/10.1101/2021.09.08.21263248; this version posted September 12, 2021. The copyright holder for this preprint (which was not certified by peer review) is the author/funder, who has granted medRxiv a license to display the preprint in perpetuity. It is made available under a CC-BY-NC-ND 4.0 International license .

(A)

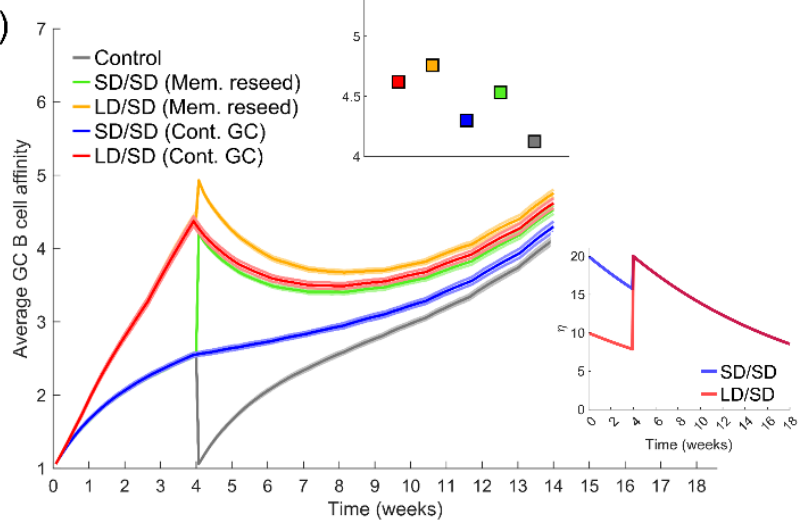

$\uparrow \Delta=28$ days $\uparrow$

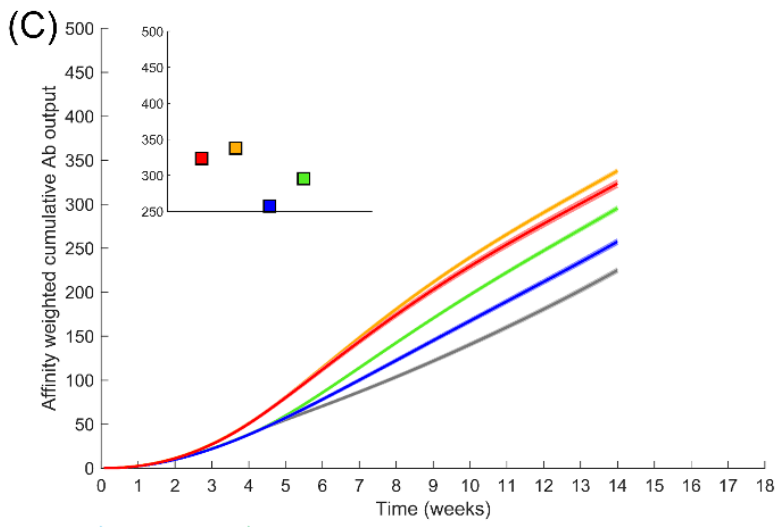

$\uparrow \Delta=28$ days $\uparrow$

(E)

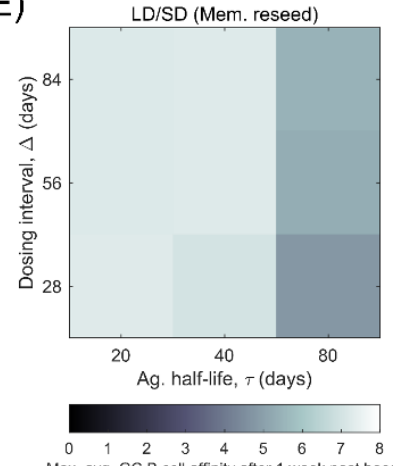

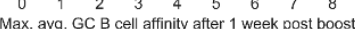

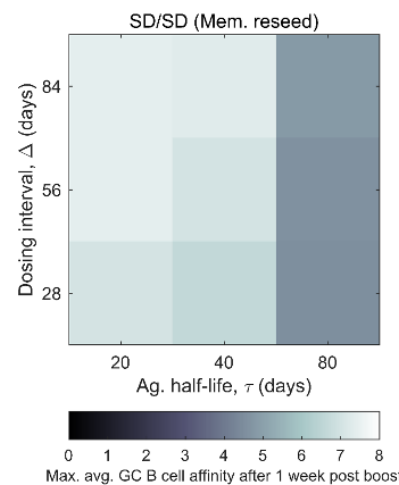

$(\mathrm{F})$
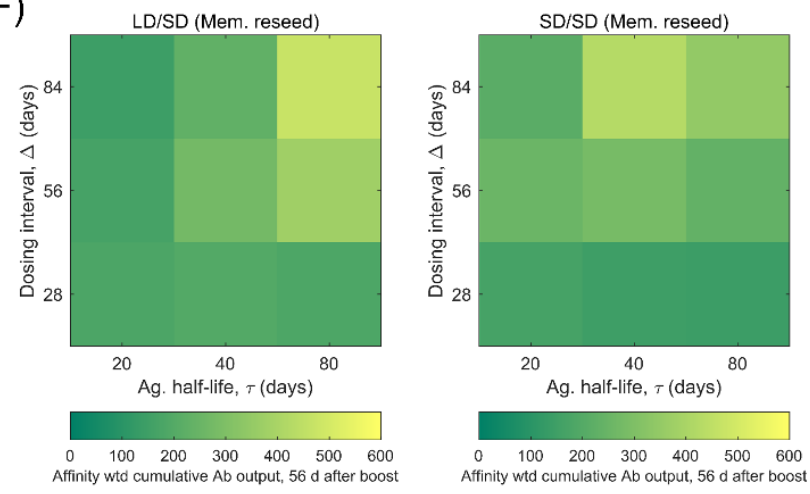

(B)

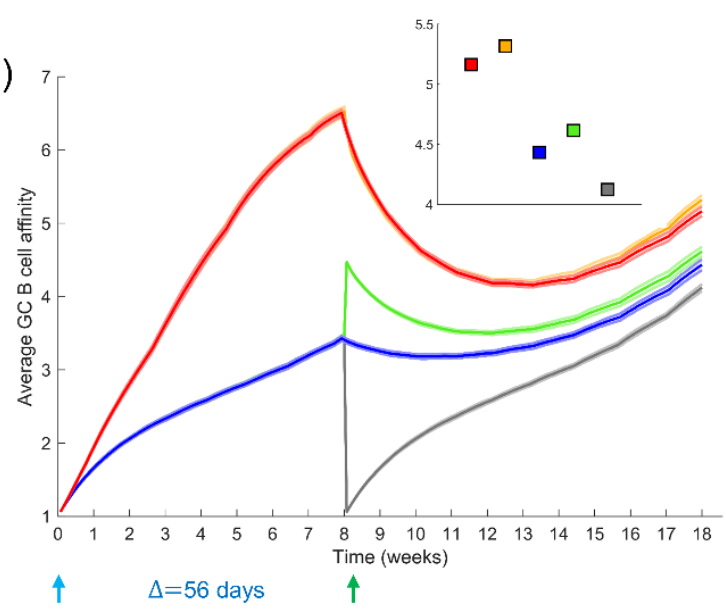

(D)
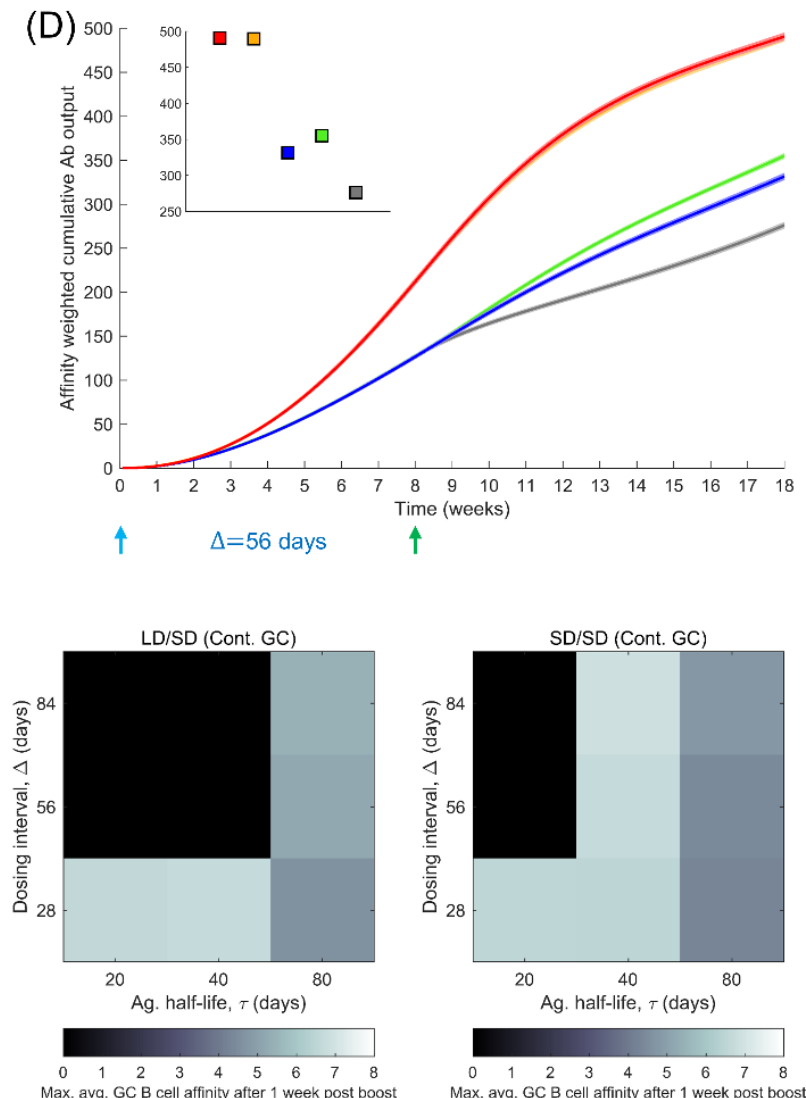
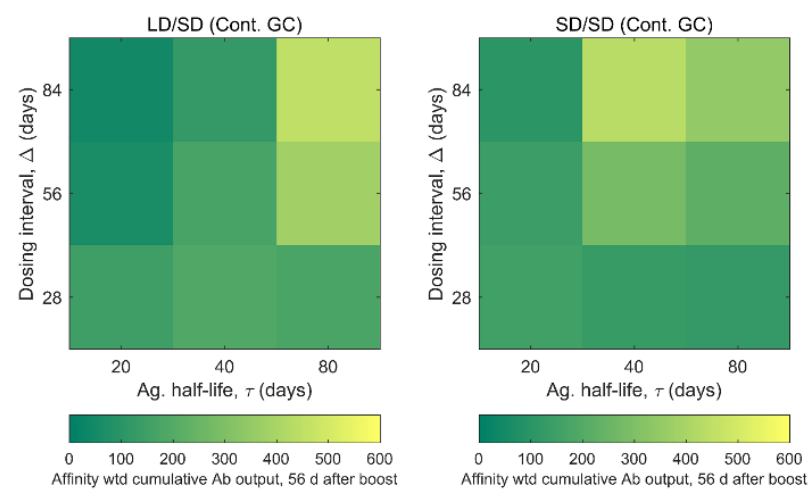
It is made available under a CC-BY-NC-ND 4.0 International license .

301 Figure 4. Influence of prime-boost dosing interval. (A, B) Average GC B cell affinities, and 302 (C, D) affinity-weighted Ab outputs, with prime-boost intervals $(\Delta)$ of either $28 \mathrm{~d}(\mathrm{~A}, \mathrm{C})$ or 56 $303 \mathrm{~d}(\mathrm{~B}, \mathrm{D})$, and with $\mathrm{LD} / \mathrm{SD}$ or SD/SD dosing. Bottom inset of (A): LD and SD correspond to $304 \eta_{0}=10$ and 20 , respectively, with $\tau=80 \mathrm{~d}$. Top insets in (A-D): values at the final time point. 305 Heatmaps of (E) the maximum GC affinity recorded between 1 week post boost administration 306 and the final time point, and (F) the affinity-weighted cumulative Ab output $28 \mathrm{~d}$ post the boost, 307 as a function of $\tau(20,40$ and $80 \mathrm{~d})$ and $\Delta(4,8$, and 12 weeks) for the two limiting scenarios 308 (Mem. reseed and Cont. GC). Trajectories corresponding to the heatmaps are shown in Figure 309 S4. Black regions in (E) correspond to collapsed GCs. A heatmap of the affinity-weighted 310

have expanded sufficiently before the boost. With low $\tau$, leading to high selection stringency, 313 GCs tended to collapse after the boost (Fig. S4). With large $\tau$, the selection stringency was

weaker and it therefore took longer for affinities to rise. Consequently, intermediate $\tau$ yielded the best response (Fig. 4F). as $\tau$ increased, but weaker selection due to greater antigen availability led to poorer affinity maturation (Fig. S4). The trade-off tended to yield the best response at intermediate $\tau$. In our simulations, when the boost contributed to existing GCs, it was not efficient in rescuing GCs that were beginning to collapse. Thus, with low and intermediate $\tau$, GCs tended to collapse (Fig. S4). When the boost was assumed to seed new GCs using memory cells from the prime, because the latter had higher affinities for the antigen, the GCs not only survived, but also expanded. The benefit was amplified with delayed dosing as better memory cells became available for seeding the GCs. Thus, as long as $\tau$ was not too small, the cumulative output 325 tended to improve with increasing $\Delta$ (see $\tau=40 \mathrm{~d}$ and $80 \mathrm{~d}$ in Fig. $4 \mathrm{~F}$ ). (With very small $\tau$, the 326 increased GC collapse compromised the response at high $\Delta$; see $\tau=20 \mathrm{~d}$ in Fig. 4F). These 
327 trends were maintained when the output was considered $56 \mathrm{~d}$ post boost (Fig. S4). That GCs 328 following COVID-19 vaccination can persist over extended durations (24) suggests that GC 329 shrinkage may be slow in vivo. Large dosing intervals would then improve responses, as has 330 been observed in clinical trials (9).

\section{DISCUSSION}

delaying the boost dose or using a low dose prime would aid optimal deployment of vaccines, efficacy. To our knowledge, ours is the first study to employ such simulations to assess the versus standard dose prime and different dosing intervals-affect this trade-off. With low dose prime, antigen availability in the GCs is lowered, resulting in the selection of high affinity GC B cells. The boost relaxes the selection stringency and allows the expansion of the selected B 345 cells. Delaying the boost delays the relaxation, resulting in even higher affinity B cells getting 346 selected following the prime. Following the boost, these latter B cells would result in better 
medRxiv preprint doi: https://doi.org/10.1101/2021.09.08.21263248; this version posted September 12,2021 . The copyright holder for this preprint (which was not certified by peer review) is the author/funder, who has granted medRxiv a license to display the preprint in perpetuity.

It is made available under a CC-BY-NC-ND 4.0 International license .

CoV-2 spike were measured in individuals administered the boost 8-12 weeks, 15-25 weeks, and 44-45 weeks after the prime (9). The titres were consistently higher in the individuals with

351 the longer dosing intervals. However, interestingly, the titres just before the boost, were lower 352 in the individuals with the longer intervals. This was consistent with lower antibody output due 353 to declining antigen availability with time in the GC and the associated GC shrinkage. 354 Furthermore, the higher corresponding selection stringency may have resulted in the selection 355 of GC B cells and memory B cells with higher affinity, which would be expected to rescue shrinking GCs or seed new GCs better, explaining the better responses eventually observed. 357 Improved antibody responses following delayed boost dosing has now been observed with 358 multiple vaccines (9-12).

With dosing intervals smaller than 8-12 weeks or with the low dose prime, the differences in antibody titres have been less apparent $(5,8,21)$. Yet, the improvement in vaccine efficacy is substantial (5). While we have argued that this improvement may be due to the improved affinity of the antibodies, direct measurements of affinity are lacking. In vitro pseudo-typed virus neutralization efficiency of antibodies isolated $28 \mathrm{~d}$ after the boost were not significantly different between individuals administered the low dose prime or the standard dose prime or when both standard doses were administered with a $28 \mathrm{~d}$ or $56 \mathrm{~d}$ interval $(5,8$, 21). It is possible that the improvements in affinity may not be adequate to be manifested as improved in vitro neutralization efficiencies, possibly because the stoichiometry of antibody binding to the viral spike proteins that ensures virus neutralization (55-57), which is yet to be 369 estimated for SARS-CoV-2, may be realized in both scenarios. In vitro neutralization 
medRxiv preprint doi: https://doi.org/10.1101/2021.09.08.21263248; this version posted September 12,2021 . The copyright holder for this

preprint (which was not certified by peer review) is the author/funder, who has granted medRxiv a license to display the preprint in perpetuity.

It is made available under a CC-BY-NC-ND 4.0 International license .

370 efficiencies tend to be much higher than corresponding in vivo efficiencies (58). Nonetheless,

371 greater affinity maturation with lower antigen availability has been long recognized as a

372 hallmark of the GC reaction $(26,34,35,39)$. In independent studies on HIV vaccination, for

373 instance, protocols that allowed antigen levels to rise with time, akin to low dose prime

374 followed by standard dose boost examined here, elicited better antibody responses than

375 protocols that held the antigen levels constant or allowed them to decline with time (34), an

376 effect consistent with the dosing protocols modulating antigen availability and the associated

377 quality-quantity trade-off in the GCs (39).

378

Our simulations predicted a role for antigen half-life in the response to vaccination. With

379 longer half-lives, the response improved upon increasing the dosing interval. With shorter half-

380 lives, if associated GC shrinkage was too drastic before the administration of the boost, the

381 response following the boost was compromised. Shorter dosing intervals then elicited the best

382 response. We note here that the antigen half-life in the GC may be difficult to estimate $(34,51$,

383 52). That GC B cells and plasmablasts were detectable in high frequencies even 12 weeks after

384 the boost suggests that antigen presented by COVID-19 vaccines may be much longer lasting

385 in the GCs than expected from their half-life in circulation (24). Such prolonged GC responses

386 have been observed in other settings (25). Future studies may yield accurate estimates of the

387 antigen half-life in GCs, which would help identify optimal dosing intervals for the different

388 COVID-19 vaccines available.

Quantitative comparison of our predictions with experimental observations is difficult,

390 as has been the case with other modeling studies of the GC reaction $(34-36,39,40,42,45)$.

391 This is because a number of key biological processes associated with the GC reaction remain 
medRxiv preprint doi: https://doi.org/10.1101/2021.09.08.21263248; this version posted September 12,2021 . The copyright holder for this

It is made available under a CC-BY-NC-ND 4.0 International license .

392 to be elucidated, including the link between dosage and the number of GCs seeded, and between 393 measurable antigen levels in circulation and those within individual GCs $(22,23,34,35,39)$. 394 Only recently have these links begun to be evaluated (37). As a simplification, our simulations 395 have assumed that increased dosage leads to increased antigen availability within GCs while 396 keeping the number of GCs seeded fixed. It is possible that the number of GCs seeded may 397 also increase with dosage but with a commensurately smaller rise in the antigen levels per GC. 398 Future studies that elucidate the links above may help define these quantities better. 399 Nonetheless, the poorer quality of the antibody response with increasing dosage is a widely 400 observed and accepted phenomenon $(26,34,39)$, giving us confidence in our findings.

401 We recognize that other arms of the immune system that could be triggered by the 402 vaccines, particularly $\mathrm{T}$ cells, may affect the vaccine efficacies realized $(5-9,13,14)$. The 403 strength and timing of the $\mathrm{T}$ cell response has been argued to be important in determining the 404 severity of the infection (59), which in turn may affect the estimated vaccine efficacy (60). We 405 have focused here on the antibody response, to which the efficacies have been found to be 406 strongly correlated $(18,19,60)$, and which in our simulations qualitatively explained the effects 407 of the different dosing protocols on vaccine efficacies. Other hypotheses have been proposed to explain the effects of low dose prime and 409 delayed dosing intervals, the predominant of which has been the undesirable response to the 410 adenoviral vector in the case of the Oxford/AstraZeneca vaccine that could blunt the response 411 to the boost (61). While these hypotheses remain to be tested, that the effects are now evident 412 with more than one vaccine, including lipid nanoparticle mRNA vaccines that do not use the 
It is made available under a CC-BY-NC-ND 4.0 International license .

413 adenoviral vectors (10-13), suggests that the effects are intrinsic to the responses elicited by

414 the SARS-CoV-2 antigens in the vaccines, supporting our hypothesis.

In summary, our study offers an explanation of the confounding effects of different

416 dosages and dosing protocols on COVID-19 vaccine efficacies. The resulting insights would

417 inform studies aimed at designing optimal vaccine deployment strategies.

\section{METHODS}

420

421

422

423

424

425

426

427 428 429 430 431 432 433 chosen positions. This ensured that the cells in the initial pool all had low affinities for the 434 antigen. The B cells were then allowed to acquire antigen. 
medRxiv preprint doi: https://doi.org/10.1101/2021.09.08.21263248; this version posted September 12,2021 . The copyright holder for this

preprint (which was not certified by peer review) is the author/funder, who has granted medRxiv a license to display the preprint in perpetuity.

It is made available under a CC-BY-NC-ND 4.0 International license .

435 Antigen acquisition. Antigen is presented to B cells as antibody-bound immune complexes on

436 follicular dendritic cell surfaces. The probability with which a B cell successfully acquired the

437 antigen was $f_{A g}=(\varepsilon-\omega+L) / 2 L$, where $\varepsilon$ and $\omega$ are the lengths of the longest common

438 substrings of the antigen sequence and those of the associated B cell receptor (BCR) and the

439 presenting antibody, respectively. The latter expression followed from a mechanistic

440 consideration of bond dissociation triggered by the competition between the BCR and the

441 antibody for the antigen (39). Note that antibodies are secreted versions of the BCRs and hence

442 were similarly represented as bit-strings of length $L$ too. The presenting antibodies were

443 produced by plasma cells and re-entered the GC via antibody feedback, described below. B

444 cells were selected at random for antigen acquisition, with each B cell selected $\eta$ times on

445 average. The amount of antigen acquired by a B cell was set equal to the number of successful

446 acquisition attempts, denoted as $\theta$. B cells had to acquire a minimum amount of antigen,

447 denoted $\theta_{c}$, for them to survive. Surviving cells were eligible to receive help from $T$ follicular

448 helper $\left(\mathrm{T}_{\mathrm{fh}}\right)$ cells. We capped the level of antigen acquired at $\theta_{\infty}$, at which point the $\mathrm{B}$ cell may

449 have received saturating levels of stimulatory signals necessary for $\mathrm{T}_{\mathrm{fh}}$ cell help.

$450 \boldsymbol{T}_{f h}$ cell help. We chose surviving B cells randomly and let each cell receive $\mathrm{T}_{\text {fh }}$ cell help with

451 the probability $f_{T}=\left(\theta-\theta_{\min }\right) /\left(\theta_{\max }-\theta_{\min }\right)$, where $\theta_{\min }$ is the minimum antigen acquired by the

452 surviving $\mathrm{B}$ cells and $\theta_{\max }\left(=\min \left(\eta, \theta_{\infty}\right)\right)$ is the maximum antigen acquired. The probability

453 follows from the recognition that $\mathrm{T}_{\text {fh }}$ cell help depends on the relative and not absolute amount

454 of antigen acquired $(23,39)$. Cells that do not receive help died. We continued this with every

455 surviving cell and stopped if 250 cells successfully received $\mathrm{T}_{\text {fh }}$ help. 
Cell fate decision. Of the cells selected above, we chose $5 \%$ randomly to become memory B

457

458

459

460

461

462

463

464

465

466

467

468

469

470

471

472

473

474

475

476

477

cells; $5 \%$ to become plasma cells; and the rest to migrate to the dark zone of the GC. The memory B cells were constrained to have a minimum affinity for the antigen (54) (here, match length 3) and were allowed to survive long-term. The plasma cells exited the GC, commenced producing antibodies, and died at the rate of 0.015 per generation (Table S1).

Proliferation and mutation. The cells in the dark zone were allowed to multiply, with each cell dividing twice. Of the resulting cells, we chose $10 \%$ and introduced single random point mutations in their BCR sequences. The latter frequency was chosen following estimates based on the somatic hypermutation frequency suggesting that 1 in $10 \mathrm{GC} \mathrm{B}$ cells would be mutated per generation in their antibody variable region genes $(23,36,39,42)$. The two divisions per cell would bring the cell population back to the $\mathrm{N} \sim 1000$ cells. This completed one generation of $\mathrm{B}$ cell evolution in the GC.

Recycling. The resulting cells in the dark zone were all allowed to migrate to the light zone, offering the next generation of cells on which the above process would repeat.

Antibody feedback. Antibodies produced by plasma cells could traffic back to the GC and influence antigen presentation (35). Accordingly, following estimated trafficking timescales, we let antibodies produced by plasma cells in any generation become the antibodies presenting antigen to B cells two generations later $(35,39)$. Antibodies were also systemically cleared at the rate of 0.01165 per generation (Table S1).

Termination. We repeated the above process for up to 250 generations ( $\sim 18$ weeks) or if the cell population declined, leading to GC collapse. 
medRxiv preprint doi: https://doi.org/10.1101/2021.09.08.21263248; this version posted September 12, 2021. The copyright holder for this preprint (which was not certified by peer review) is the author/funder, who has granted medRxiv a license to display the preprint in perpetuity. It is made available under a CC-BY-NC-ND 4.0 International license .

478

479

480

481

482

483

484

485

486

487

488

489

490

491

492

493

494

495

496

497

498

499

\section{Dosing protocol}

We implemented the prime-boost dosing protocol by letting $\eta$ vary with time as $\eta=\eta_{0} \exp (-\mathrm{t} \times \ln 2 / \tau)$, mimicking antigen rise immediately upon dosing (to $\left.\eta_{0}\right)$ and an exponential decline subsequently with half-life $\tau(34,39,46)$. The decline is assumed to subsume any loss of antigen due to acquisition by B cells. We set $\eta_{0}$ based on whether a low or standard dose was employed. The prime and boost were separated by the duration $\Delta$. Our interest is in large values of $\Delta$ and low first dosages, so that at the time of boost administration, the residual antigen is small. Whether memory B cells seed GCs post boost is a topic of active current research (47, $48,53,54,62,63)$. We therefore considered all potential scenarios, with the boost 1) feeding into existing GCs; 2) seeding new GCs using memory B cells; 3) seeding new GCs using naïve B cells. In scenario 2, we let the memory B cells for seeding the GCs be chosen with a probability proportional to their affinity for the antigen. In other words, the distribution of B cells of different affinities in the seeder pool mimics the distribution of affinity-weighted fractions of memory B cells formed following the prime.

\section{Parameter values}

The parameter values employed and their sources are listed in Table S1.

\section{Quantification of the GC response}

With each parameter setting, we performed 2500 realizations, which we divided into 25 ensembles of $100 \mathrm{GC}$ realizations each (39). The average GC B cell affinity in the $g^{\text {th }}$ generation was calculated using, 


$$
\alpha(g)=\left\langle\frac{\sum_{i=1}^{100} \sum_{j=1}^{n_{i}(g)} a_{i j}(g)}{\sum_{i=1}^{100} n_{i}(g)}\right\rangle_{25}
$$

501 where $a_{i j}$ was the affinity of the $j^{\text {th }} \mathrm{B}$ cell among the $n_{i}(g) \mathrm{B}$ cells in the $g^{\text {th }}$ generation of the $i^{\text {th }}$ 502 realization of an ensemble. The angular brackets represent averaging across the ensembles. The 503 affinity-weighted plasma cell output in the $g^{\text {th }}$ generation was

504

$$
w(g)=\left\langle\sum_{i=1}^{100} \sum_{\varepsilon=1}^{L} p_{\varepsilon}^{i}(g) \frac{\varepsilon}{L}\right\rangle_{25}
$$

505 where $p_{\varepsilon}^{i}(g)$ was the number of plasma cells with affinity $\varepsilon$ in the $g^{\text {th }}$ generation. If plasma cells 506 died at the per capita rate $\delta_{\mathrm{p}}$, then the affinity-weighted cumulative plasma cell output would 507 be

$$
P(g)=\sum_{\varphi=1}^{g} w(\varphi) \exp \left(-\delta_{p}(g-\varphi)\right)
$$

509 If the antibody production rate of plasma cells was $\beta$ per generation (64), the instantaneous 510 affinity-weighted antibody output would be $\beta \mathrm{P}(\mathrm{g})$, which given the clearance rate, $\delta_{\mathrm{A}}$, of 511 circulating antibodies yielded the affinity-weighted cumulative antibody output as

$$
\gamma(g)=\sum_{\varphi=1}^{g} \beta P(\varphi) \exp \left(-\delta_{A}(g-\varphi)\right)
$$

513 We performed the simulations and analysed the results using programs written in MATLAB.

\section{COMPETING INTERESTS}

516 The authors declare that no conflicts of interests exist. 
It is made available under a CC-BY-NC-ND 4.0 International license .

\section{REFERENCES}

1. O. J. Wouters et al., Challenges in ensuring global access to COVID-19 vaccines: production, affordability, allocation, and deployment. Lancet 397, 1023-1034 (2021).

2. G. Forni, A. Mantovani, COVID-19 vaccines: where we stand and challenges ahead. Cell Death Differ 28, 626-639 (2021).

3. C. M. Saad-Roy et al., Epidemiological and evolutionary considerations of SARS-CoV-2 vaccine dosing regimes. Science 10.1126/science.abg8663 (2021).

4. K. M. Bubar et al., Model-informed COVID-19 vaccine prioritization strategies by age and serostatus. Science 371, 916-921 (2021).

5. M. Voysey et al., Single-dose administration and the influence of the timing of the booster dose on immunogenicity and efficacy of ChAdOx1 nCoV-19 (AZD1222) vaccine: a pooled analysis of four randomised trials. Lancet 397, 881-891 (2021).

6. M. Voysey et al., Safety and efficacy of the ChAdOx1 nCoV-19 vaccine (AZD1222) against SARSCoV-2: an interim analysis of four randomised controlled trials in Brazil, South Africa, and the UK. Lancet 397, 99-111 (2021).

7. P. M. Folegatti et al., Safety and immunogenicity of the ChAdOx $1 \mathrm{nCoV}-19$ vaccine against SARSCoV-2: a preliminary report of a phase $1 / 2$, single-blind, randomised controlled trial. Lancet 396, 467-478 (2020).

8. M. N. Ramasamy et al., Safety and immunogenicity of ChAdOx1 nCoV-19 vaccine administered in a prime-boost regimen in young and old adults (COV002): a single-blind, randomised, controlled, phase 2/3 trial. Lancet 396, 1979-1993 (2021).

9. A. Flaxman et al., Tolerability and immunogenicity after a late second dose or a third dose of ChAdOx1 nCoV-19 (AZD1222). Preprint 10.2139/ssrn.3873839., https://papers.ssrn.com/sol3/papers.cfm?abstract_id=3873839 (2021).

10. H. Parry et al., Extended interval BNT162b2 vaccination enhances peak antibody generation in older people. medRxiv 10.1101/2021.05.15.21257017, 2021.2005.2015.21257017 (2021).

11. H. Victoria et al., Delayed interval BNT162b2 mRNA COVID-19 vaccination provides robust immunity. Nature Portfolio 10.21203/rs.3.rs-793234/v1 (2021).

12. R. Payne et al. (2021) Sustained T cell immunity, protection and boosting using extended dosing intervals of BNT162b2 mRNA vaccine. https://www.pitchstudy.org/PITCH_Dosing_Interval_23072021.pdf

13. J. Mateus et al., Low dose mRNA-1273 COVID-19 vaccine generates durable T cell memory and antibodies enhanced by pre-existing crossreactive T cell memory. medRxiv 10.1101/2021.06.30.21259787, 2021.2006.2030.21259787 (2021).

14. M. Sadarangani, A. Marchant, T. R. Kollmann, Immunological mechanisms of vaccine-induced protection against COVID-19 in humans. Nat Rev Immunol 21, 475-484 (2021).

15. L. R. Baden et al., Efficacy and safety of the mRNA-1273 SARS-CoV-2 vaccine. N Engl J Med 384, 403-416 (2021).

16. D. Y. Logunov et al., Safety and efficacy of an rAd26 and rAd5 vector-based heterologous primeboost COVID-19 vaccine: an interim analysis of a randomised controlled phase 3 trial in Russia. Lancet 397, 671-681 (2021).

17. F. P. Polack et al., Safety and efficacy of the BNT162b2 mRNA COVID-19 Vaccine. N Engl J Med 383, 2603-2615 (2020).

18. D. S. Khoury et al., Neutralizing antibody levels are highly predictive of immune protection from symptomatic SARS-CoV-2 infection. Nat Med 10.1038/s41591-021-01377-8 (2021).

19. K. A. Earle et al., Evidence for antibody as a protective correlate for COVID-19 vaccines. Vaccine 39, 4423-4428 (2021).

20. F. Krammer, A correlate of protection for SARS-CoV-2 vaccines is urgently needed. Nat Med 27, 1147-1148 (2021). 
medRxiv preprint doi: https://doi.org/10.1101/2021.09.08.21263248; this version posted September 12, 2021. The copyright holder for this

preprint (which was not certified by peer review) is the author/funder, who has granted medRxiv a license to display the preprint in perpetuity.

It is made available under a CC-BY-NC-ND 4.0 International license .

567 21. J. R. Barrett et al., Phase 1/2 trial of SARS-CoV-2 vaccine ChAdOx1 nCoV-19 with a booster dose

568

569

570

571

572

573

574

575

576

577

578

579

580

581

582

583

584

585

586

587

588

589

590

591

592

593

594

595

596

597

598

599

600

601

602

603

604

605

606

607

608

609

610

611

612

613

614

615

616

617 induces multifunctional antibody responses. Nat Med 27, 279-288 (2021).

22. J. G. Cyster, C. D. C. Allen, B cell responses: cell interaction dynamics and decisions. Cell 177, 524540 (2019).

23. G. D. Victora, M. C. Nussenzweig, Germinal centers. Annu Rev Immunol 30, 429-457 (2012).

24. J. S. Turner et al., SARS-CoV-2 mRNA vaccines induce persistent human germinal centre responses. Nature 10.1038/s41586-021-03738-2 (2021).

25. C. W. Davis et al., Longitudinal analysis of the human B cell response to Ebola virus infection. Cell 177, 1566-1582.e1517 (2019).

26. H. N. Eisen, G. W. Siskind, Variations in affinities of antibodies during the immune response.

Biochemistry 3, 996-1008 (1964).

27. M. Bonsignori et al., Maturation pathway from germline to broad HIV-1 neutralizer of a CD4-mimic antibody. Cell 165, 449-463 (2016).

28. J. Foote, H. N. Eisen, Kinetic and affinity limits on antibodies produced during immune responses. Proc Natl Acad Sci U S A 92, 1254-1256 (1995).

29. J. Foote, H. N. Eisen, Breaking the affinity ceiling for antibodies and T cell receptors. Proc Natl Acad Sci U S A 97, 10679-10681 (2000).

30. R. Desikan, R. Antia, N. M. Dixit, Physical 'strength' of the multi-protein chain connecting immune cells: Does the weakest link limit antibody affinity maturation? Bioessays 43, e2000159 (2021).

31. J. M. Tas et al., Visualizing antibody affinity maturation in germinal centers. Science 351, 1048-1054 (2016).

32. E. Natkanski et al., B cells use mechanical energy to discriminate antigen affinities. Science 340, 1587-1590 (2013).

33. K. Kwak et al., Intrinsic properties of human germinal center B cells set antigen affinity thresholds. Sci Immunol 3 (2018).

34. H. H. Tam et al., Sustained antigen availability during germinal center initiation enhances antibody responses to vaccination. Proc Natl Acad Sci U S A 113, E6639-E6648 (2016).

35. Y. Zhang et al., Germinal center B cells govern their own fate via antibody feedback. J Exp Med 210, 457-464 (2013).

36. S. Wang et al., Manipulating the selection forces during affinity maturation to generate cross-reactive HIV antibodies. Cell 160, 785-797 (2015).

37. Y. Kato et al., Multifaceted effects of antigen valency on B cell response composition and differentiation in vivo. Immunity 53, 548-563 e548 (2020).

38. T. Schoofs et al., HIV-1 therapy with monoclonal antibody 3BNC117 elicits host immune responses against HIV-1. Science 352, 997-1001 (2016).

39. A. K. Garg, R. Desikan, N. M. Dixit, Preferential presentation of high-affinity immune complexes in germinal centers can explain how passive immunization improves the humoral response. Cell Rep 29, 3946-3957 e3945 (2019).

40. R. J. De Boer, A. S. Perelson, How germinal centers evolve broadly neutralizing antibodies: The breadth of the follicular helper T cell response. J Virol 91 (2017).

41. M. Meyer-Hermann et al., A theory of germinal center B cell selection, division, and exit. Cell Rep 2 , 162-174 (2012).

42. S. Luo, A. S. Perelson, Competitive exclusion by autologous antibodies can prevent broad HIV-1 antibodies from arising. Proc Natl Acad Sci U S A 112, 11654-11659 (2015).

43. M. Oprea, A. S. Perelson, Somatic mutation leads to efficient affinity maturation when centrocytes recycle back to centroblasts. J Immunol 158, 5155-5162 (1997).

44. T. B. Kepler, A. S. Perelson, Cyclic re-entry of germinal center B cells and the efficiency of affinity maturation. Immunol Today 14, 412-415 (1993).

45. V. I. Zarnitsyna, J. Lavine, A. Ellebedy, R. Ahmed, R. Antia, Multi-epitope models explain how preexisting antibodies affect the generation of broadly protective responses to influenza. PLoS Pathog 12, e1005692 (2016). 
medRxiv preprint doi: https://doi.org/10.1101/2021.09.08.21263248; this version posted September 12, 2021. The copyright holder for this

preprint (which was not certified by peer review) is the author/funder, who has granted medRxiv a license to display the preprint in perpetuity.

It is made available under a CC-BY-NC-ND 4.0 International license .

618 46. K. A. Pape, D. M. Catron, A. A. Itano, M. K. Jenkins, The humoral immune response is initiated in

619

620

621

622

623

624

625

626

627

628

629

630

631

632

633

634

635

636

637

638

639

640

641

642

643

644

645

646

647

648

649

650

651

652

653

654

655

656

657

658

659

660 lymph nodes by B cells that acquire soluble antigen directly in the follicles. Immunity 26, 491-502 (2007).

47. K. A. Pape, M. K. Jenkins, Do memory B cells form secondary germinal centers?: it depends. Cold Spring Harb Perspect Biol 10, a029116 (2018).

48. M. J. Shlomchik, Do memory B cells form secondary germinal centers?: yes and no. Cold Spring Harb Perspect Biol 10, a029405 (2018).

49. K. Tripathi, R. Balagam, N. K. Vishnoi, N. M. Dixit, Stochastic simulations suggest that HIV-1 survives close to its error threshold. PLoS Comput Biol 8, e1002684 (2012).

50. S. Gadhamsetty, N. M. Dixit, Estimating frequencies of minority nevirapine-resistant strains in chronically HIV-1-infected individuals naive to nevirapine by using stochastic simulations and a mathematical model. J Virol 84, 10230-10240 (2010).

51. B. A. Heesters, C. E. van der Poel, A. Das, M. C. Carroll, Antigen presentation to B cells. Trends Immunol 37, 844-854 (2016).

52. B. A. Heesters, R. C. Myers, M. C. Carroll, Follicular dendritic cells: dynamic antigen libraries. Nat Rev Immunol 14, 495-504 (2014).

53. L. J. McHeyzer-Williams, C. Dufaud, M. G. McHeyzer-Williams, Do memory B cells form secondary germinal centers?: impact of antibody class and quality of memory T-cell help at recall. Cold Spring Harb Perspect Biol 10, a028878 (2018).

54. F. Weisel, M. Shlomchik, Memory B cells of mice and humans. Ann Rev Immunol 35, 255-284 (2017).

55. O. F. Brandenberg et al., Predicting HIV-1 transmission and antibody neutralization efficacy in vivo from stoichiometric parameters. PLoS Pathog 13, e1006313 (2017).

56. S. N. Mulampaka, N. M. Dixit, Estimating the threshold surface density of Gp120-CCR5 complexes necessary for HIV-1 envelope-mediated cell-cell fusion. PLoS One 6, e19941 (2011).

57. P. Padmanabhan, N. M. Dixit, Mathematical model of viral kinetics in vitro estimates the number of E2-CD81 complexes necessary for hepatitis C virus entry. PLoS Comput Biol 7, e1002307 (2011).

58. M. J. van Gils, R. W. Sanders, In vivo protection by broadly neutralizing HIV antibodies. Trends Microbiol 22, 550-551 (2014).

59. B. Chatterjee, H. S. Sandhu, N. M. Dixit, The relative strength and timing of innate immune and CD8 T-cell responses underlie the heterogeneous outcomes of SARS-CoV-2 infection. medRxiv 10.1101/2021.06.15.21258935, 2021.2006.2015.21258935 (2021).

60. P. Padmanabhan, R. Desikan, N. M. Dixit, Modelling the population-level protection conferred by COVID-19 vaccination. medRxiv 10.1101/2021.03.16.21253742, 2021.2003.2016.21253742 (2021).

61. E. Callaway, Why Oxford's positive COVID vaccine results are puzzling scientists. Nature 588, 1618 (2020).

62. L. Mesin et al., Restricted clonality and limited germinal center reentry characterize memory B cell reactivation by boosting. Cell 180, 92-106.e111 (2020).

63. C. Viant et al., Antibody affinity shapes the choice between memory and germinal center B cell fates. Cell 183, 1298-1311.e1211 (2020).

64. K. Roberts, B. Alberts, A. Johnson, P. Walter, T. Hunt, Molecular biology of the cell. $4^{\text {th }}$ edition. New York: Garland Science (2002). 


\section{Supplementary Materials for}

662

663 Low dose prime and delayed boost can improve COVID-19 vaccine efficacies by 664 increasing B cell selection stringency in germinal centres

665

666 Amar K. Garg ${ }^{1, \#}$, Soumya Mittal ${ }^{1}$, Pranesh Padmanabhan ${ }^{2}$, Rajat Desikan ${ }^{1, \ddagger}$, Narendra M. Dixit ${ }^{1,3, *}$

667

$668{ }^{1}$ Department of Chemical Engineering, Indian Institute of Science, Bangalore, India 560012

$669{ }^{2}$ Clem Jones Centre for Ageing Dementia Research, Queensland Brain Institute, The University of Queensland,

670 Brisbane, Australia 4072

$671{ }^{3}$ Centre for Biosystems Science and Engineering, Indian Institute of Science, Bangalore, India 560012

$672{ }^{\#}$ Current Address: Helmholtz Centre for Infection Research, Braunschweig, Germany

$673{ }^{\ddagger}$ Current Address: Certara QSP, Certara UK Limited, Sheffield, UK

674

$675 *$ Correspondence:

676 Narendra M. Dixit

677 Email: narendra@iisc.ac.in 
medRxiv preprint doi: https://doi.org/10.1101/2021.09.08.21263248; this version posted September 12, 2021. The copyright holder for this preprint (which was not certified by peer review) is the author/funder, who has granted medRxiv a license to display the preprint in perpetuity.

It is made available under a CC-BY-NC-ND 4.0 International license .

679

(A) 1000

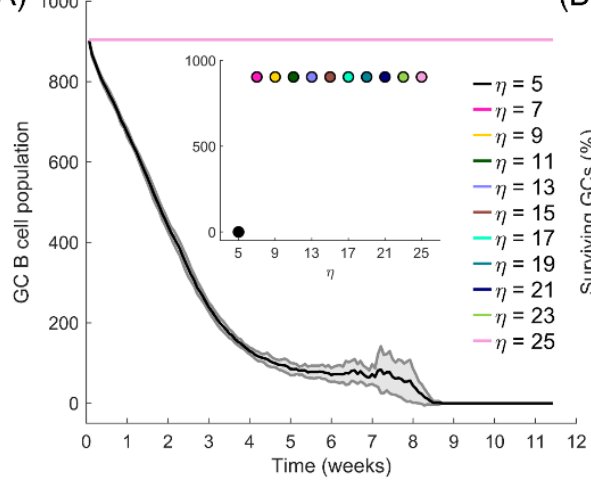

(B)

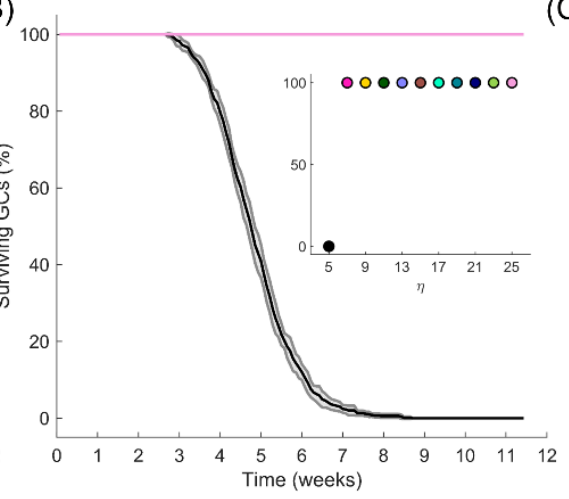

(C) 8

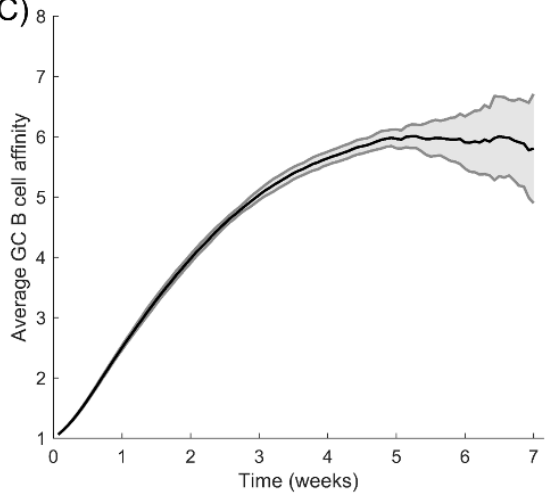

682 Figure S1. Influence of $\eta$. Time series of (A) GC B cell population and (B) percent surviving 683 GCs for simulations with various $\eta$. GCs with low $\eta$ ( $=5$ here) have high rates of apoptosis 684 which result in GCs gradually being extinguished with time. However, these GCs also exhibit 685 accelerated affinity maturation $(\mathrm{C})$ due to the higher selection stringencies. Insets: values at the 686 final time point.

687

688 
medRxiv preprint doi: https://doi.org/10.1101/2021.09.08.21263248; this version posted September 12, 2021. The copyright holder for this preprint (which was not certified by peer review) is the author/funder, who has granted medRxiv a license to display the preprint in perpetuity.
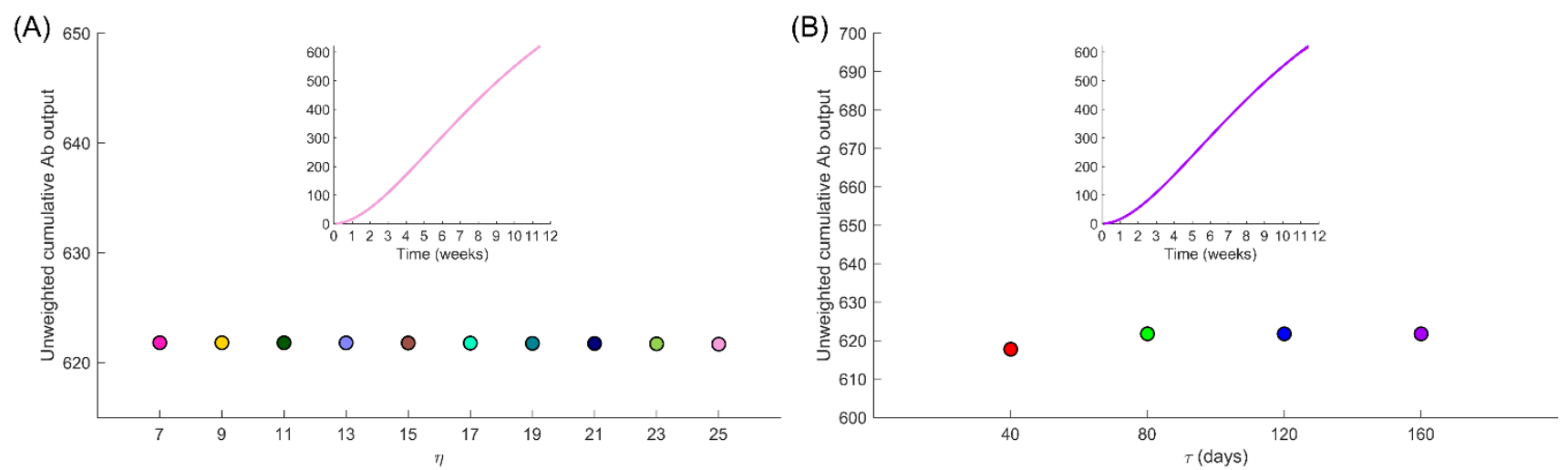

691 Figure S2. Absolute Ab output. Unweighted cumulative antibody output at the final time 692 point for various (A) $\eta$, and (B) $\tau$. Insets: time series. The curves for the different cases overlap. 693 
medRxiv preprint doi: https://doi.org/10.1101/2021.09.08.21263248; this version posted September 12, 2021. The copyright holder for this preprint (which was not certified by peer review) is the author/funder, who has granted medRxiv a license to display the preprint in perpetuity.

It is made available under a CC-BY-NC-ND 4.0 International license .

695

(A)

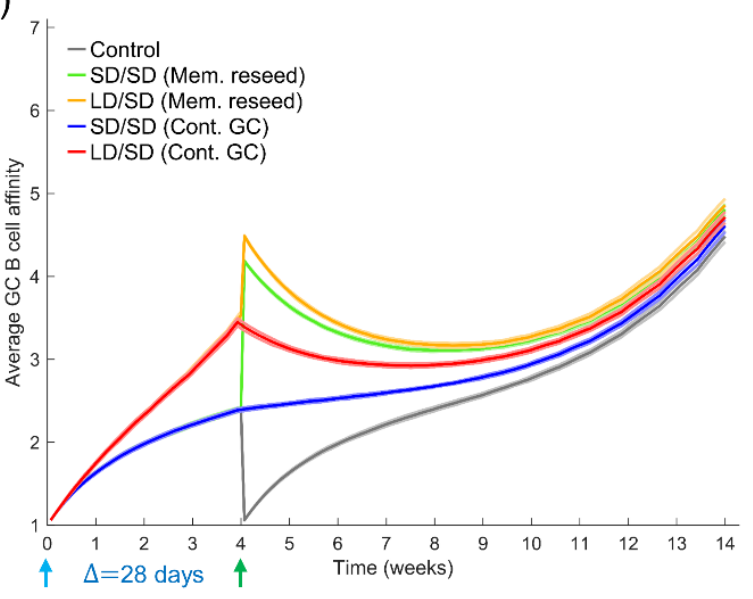

(C)

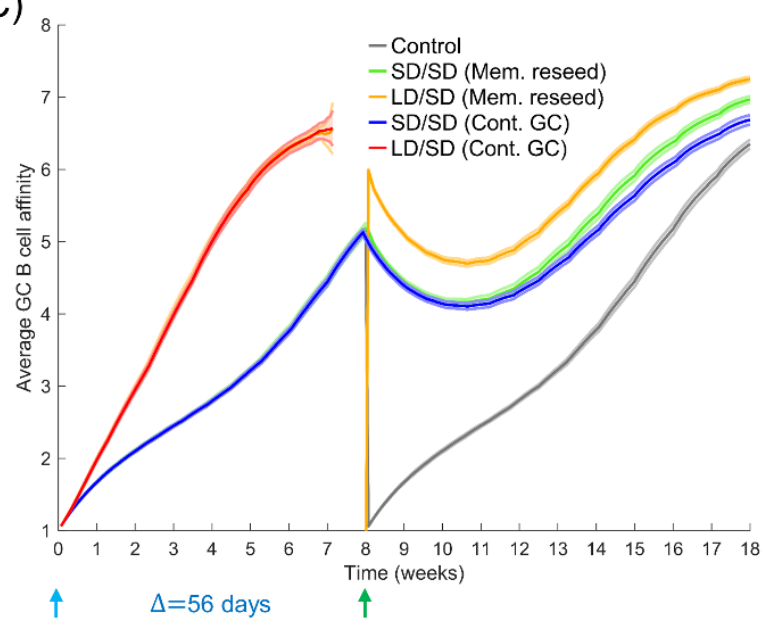

(B)

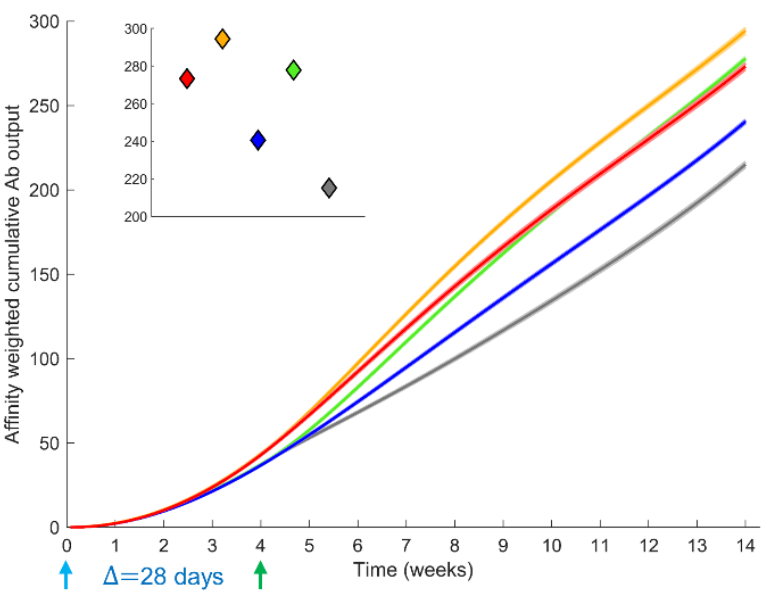

(D)

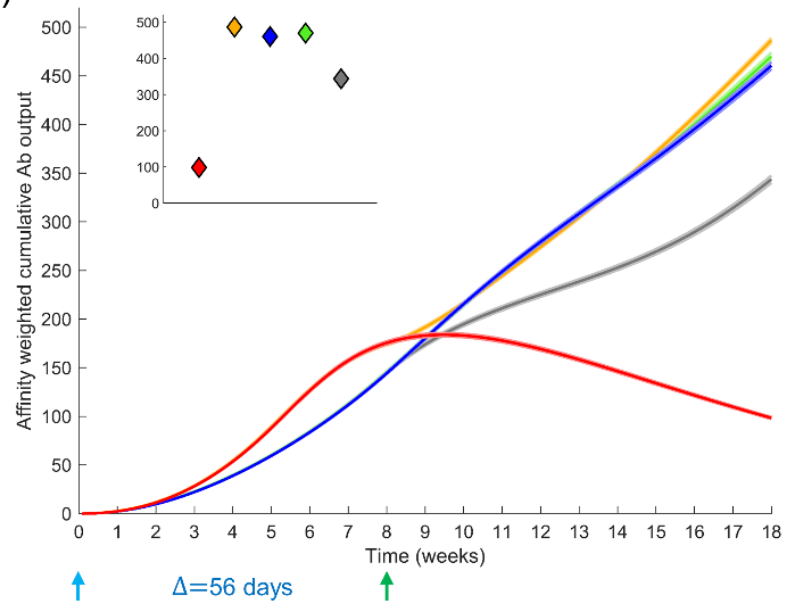

698 Figure S3. Influence of initial Ag levels (dose) and the prime-boost dosing interval $(\Delta)$. 699 (A) Average GC B cell affinity, and (B) affinity-weighted Ab output with a prime-boost 700 interval $\Delta=28 \mathrm{~d}$ and antigen half-life $\tau=40 \mathrm{~d}$, either with LD/SD or SD/SD dosing (LD and SD 701 correspond to $\eta_{0}=15$ and 30 , respectively). These trends are qualitatively similar to those in 702 Figure 3. (C) Average GC B cell affinity, and (D) affinity-weighted Ab output with $\Delta=56 \mathrm{~d}$ and $703 \tau=40 \mathrm{~d}$, either with LD/SD or SD/SD dosing (LD and SD correspond to the default $\eta_{0}=10$ and 704 20, respectively). Insets: values at the final time point. 
medRxiv preprint doi: https://doi.org/10.1101/2021.09.08.21263248; this version posted September 12, 2021. The copyright holder for this preprint (which was not certified by peer review) is the author/funder, who has granted medRxiv a license to display the preprint in perpetuity.

It is made available under a CC-BY-NC-ND 4.0 International license .

(A)

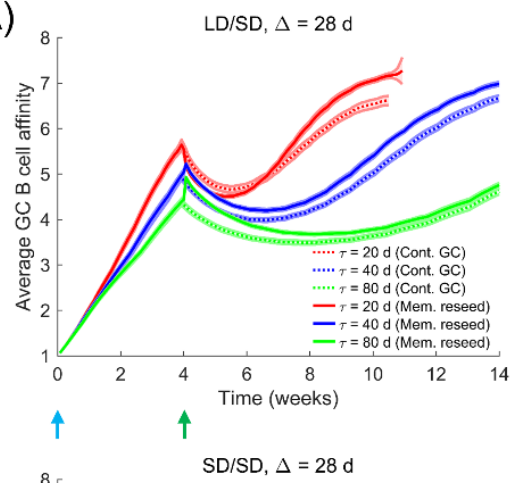

(B)
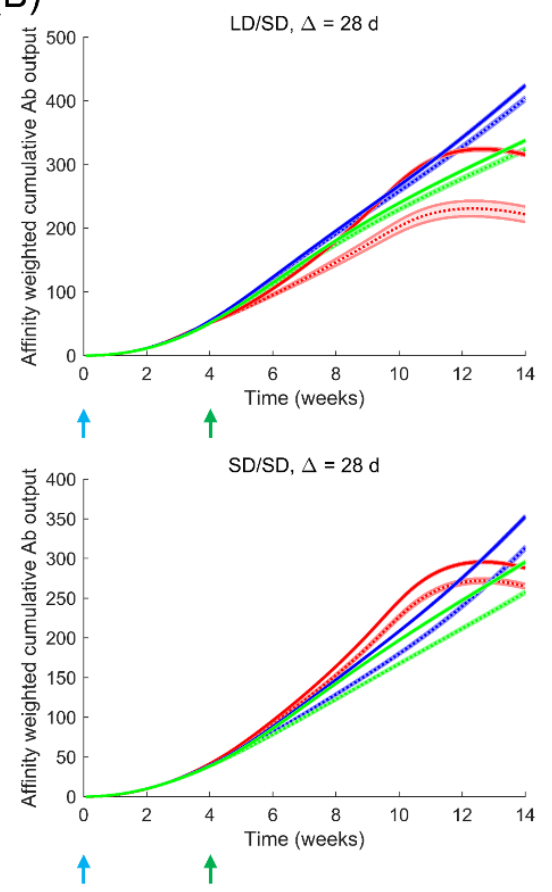

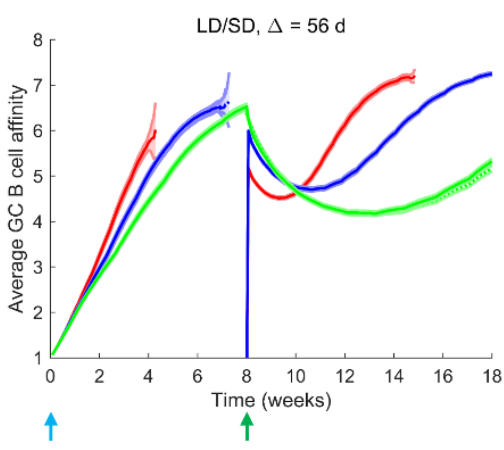

$\mathrm{SD} / \mathrm{SD}, \Delta=56 \mathrm{~d}$
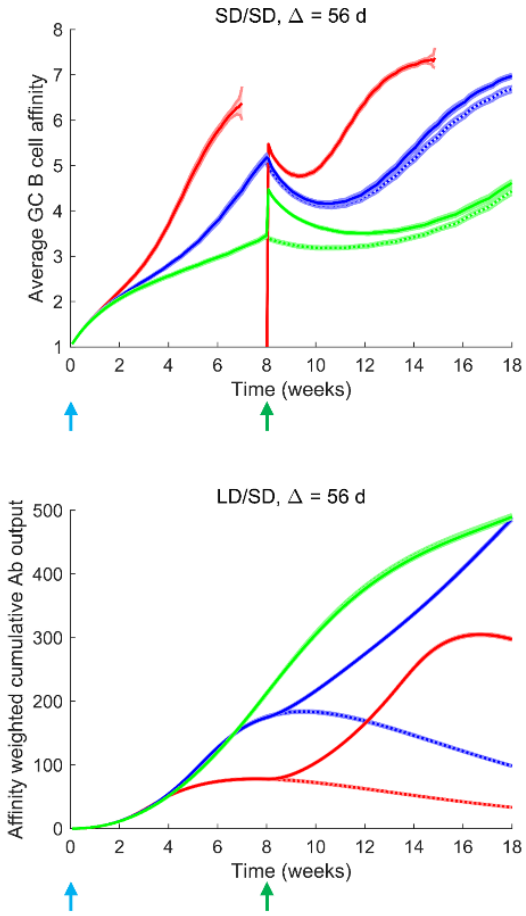

$\mathrm{SD} / \mathrm{SD}, \Delta=56 \mathrm{~d}$

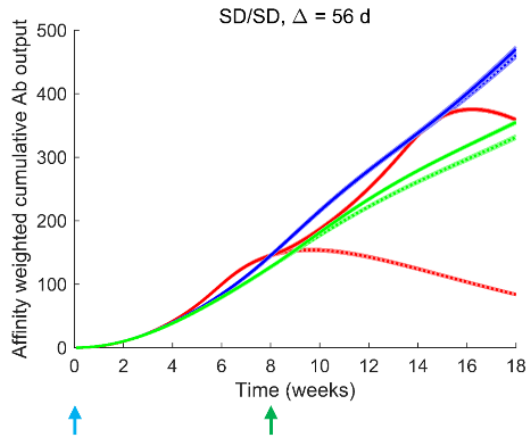

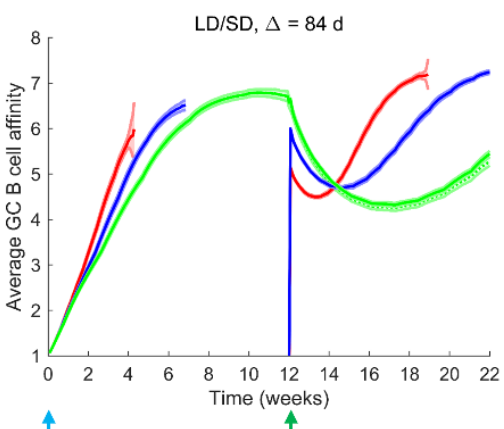

$\uparrow$

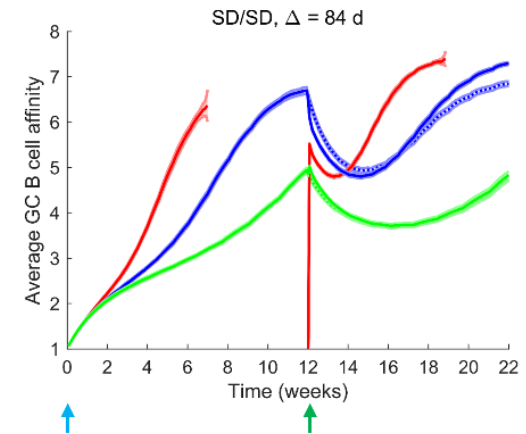

$\mathrm{LD} / \mathrm{SD}, \Delta=84 \mathrm{~d}$

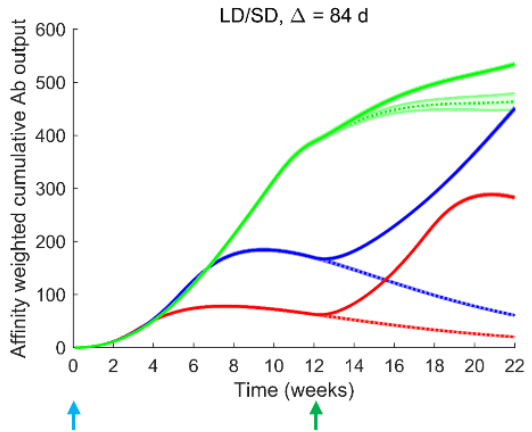

$\mathrm{SD} / \mathrm{SD}, \Delta=84 \mathrm{~d}$

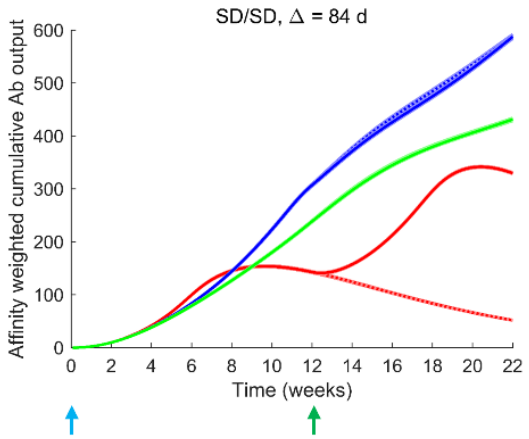

SD/SD (Cont. GC)

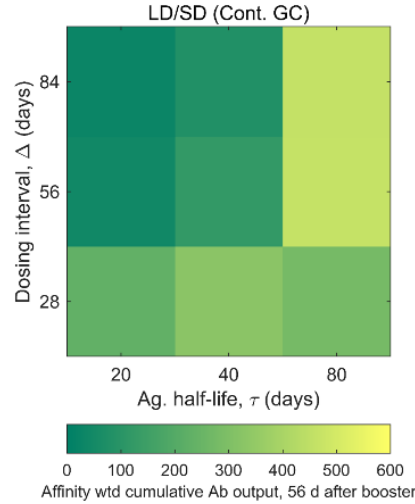

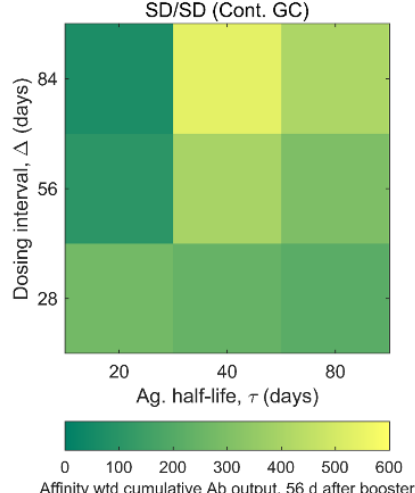

Affinity wtd cumulative Ab output, $56 \mathrm{~d}$ after booster

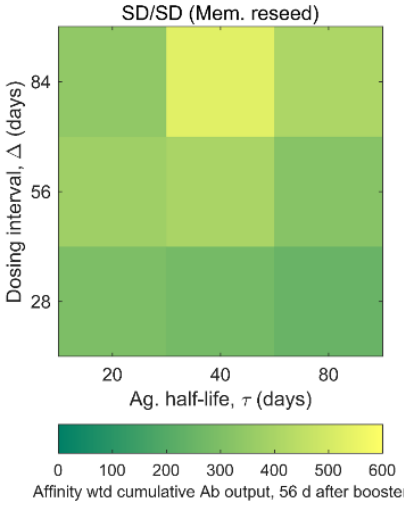


medRxiv preprint doi: https://doi.org/10.1101/2021.09.08.21263248; this version posted September 12, 2021. The copyright holder for this preprint (which was not certified by peer review) is the author/funder, who has granted medRxiv a license to display the preprint in perpetuity.

It is made available under a CC-BY-NC-ND 4.0 International license .

709 Figure S4. Influence of the prime-boost dosing interval $(\Delta)$. Time series of (A) average GC 710 B cell affinities, and (B) affinity-weighted Ab outputs corresponding to the heatmaps in Figure 711 4E and 4F, respectively. (C) Heatmaps of the affinity-weighted cumulative Ab output $56 \mathrm{~d}$ post 712 the boost, as a function of $\tau(20,40$ and $80 \mathrm{~d})$ and $\Delta(4,8$, and 12 weeks) for the two limiting 713 scenarios (Mem. reseed and Cont. GC).

714

715 
medRxiv preprint doi: https://doi.org/10.1101/2021.09.08.21263248; this version posted September 12, 2021. The copyright holder for this preprint (which was not certified by peer review) is the author/funder, who has granted medRxiv a license to display the preprint in perpetuity. It is made available under a CC-BY-NC-ND 4.0 International license .

\section{Table S1. Model parameters and their values.}

\begin{tabular}{|c|l|c|c|}
\hline Symbol & Description & Value (units) & Refs. \\
\hline $\mathrm{N}$ & Number of B cells initiating the GC reaction & 1000 (cells) & $(36,39)$ \\
$\mathrm{L}$ & String length of antigen, B cell receptor (BCR), and antibody & 8 (dimensionless) & $(39,42)$ \\
$\kappa$ & Alphabet size for strings & 4 (dimensionless) & $(39,42)$ \\
$\theta_{c}$ & Minimum amount of acquired antigen for B cell survival & 3 (dimensionless) & $(39)$ \\
$\theta_{\infty}$ & Maximum amount of antigen that can be acquired by a B cell & 5 (dimensionless) & - \\
$\delta_{p}$ & Clearance rate of plasma cells & 0.015 (generation $\left.{ }^{-1}\right)$ & $(34,44)$ \\
$\delta_{a}$ & Antibody production rate of plasma cells per generation & 2000 (molecules cell $\left.^{-1} \mathrm{~s}^{-1}\right)$ & $(64)$ \\
\hline
\end{tabular}

